\title{
PLANEJAMENTO E CONTROLE DE
}

\section{EMPRESA AGROERCOARIA}

\author{
On estudo de caso
}

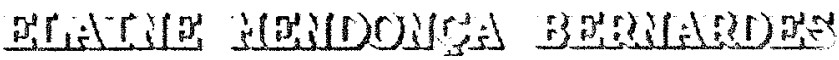

Bngenheiro Agronomo

Orientadora: Profa Dra Zilda Paes de Barros Mattos

Dissertação apresentada à Bscola Superior de Agricultura "Luiz de Queiroz" da Universidade de Sæo Paulo, para obtenção do título de Mestre ern Agronomia, Area de Concentração Bconomia Agrária

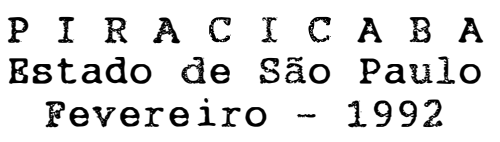


Ficha catalografica preparada pela Secaan de Liveas da Divisáo de Biblioteca e Documentasăo - PCLQ/USP

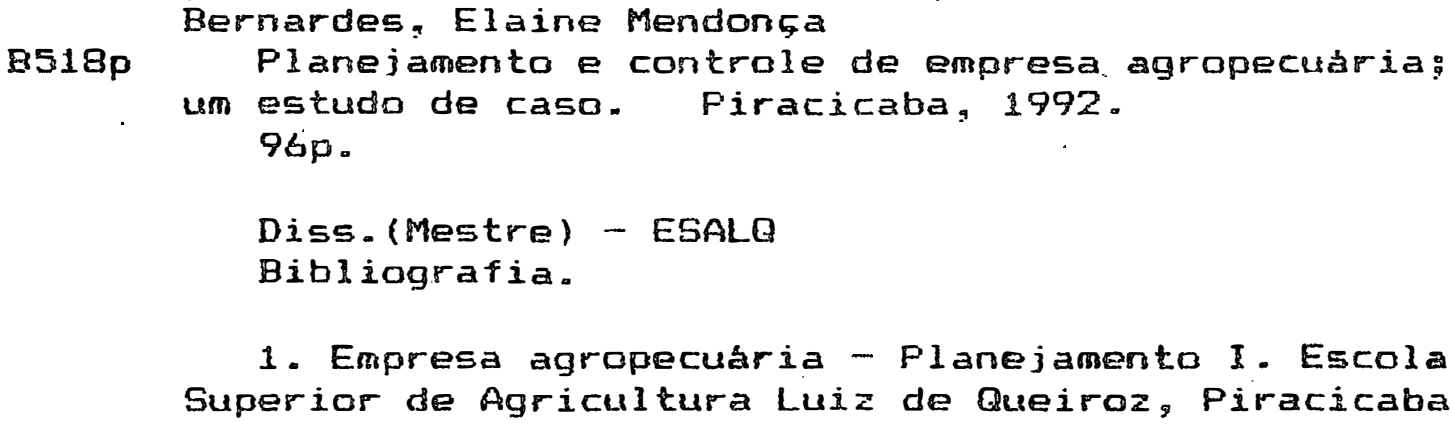

CDD $33 B .1$ 


\section{PLANEJAMENTO E CONTROLE DE EMPRESA AGROPECUÁRIA Um estudo de caso}

ELAINE MENDONGA BERMARDES

Aprovada em: 26.06 .92

Comissão Julgadora:

Prof B Dra Zilda Paes de Barros Mattos

ESALQ/USP

Prof. Dr. Fernando Curi Peres

ESALQ/USP

Profa Dra Maria Aparecida Anselmo Tarsitano

FETSAUNEP

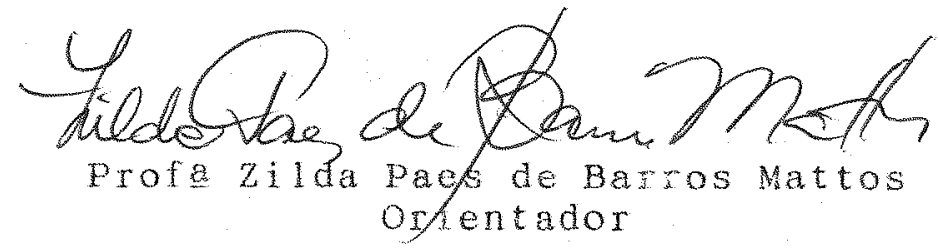


A meus pais e avós, com carinho, dedico 


\section{AGRADECIMENTOS}

A Professora Zilda paes de Barros Mattos, pela orientaçäo segura e criteriosa.

Ao Professor Fernando Curi Peres, pela valiosa contribuição e incentivo constante à realização deste trabalho.

Ao professor Marcos Bernardes, do Departamento de Agricultura da ESALQ, pelo fornecimento de dados e coeficientes técnicos da cultura de seringueira.

Ao professor Celso Boin, do Departamento de Zootecnica da ESALQ, pelas informações sobre confinamento bovino.

A pesquisadora Vera Lúcia Lobão, do Instituto de Pesca, pelos coeficientes técnicos do cultivo de camarões de água doce.

A Engo Agronomo Maria Consolação de Oliveira pelo trabalho de mapeamento dos solos da propriedade utilizada no estudo de caso.

Aos senhores César e Miguel Cestari, pela decisiva colaboração no estudo de caso. 
Aos Professores e Funcionátios do

Departamento de Econonia e Sociologia da ESALQ, pela oportunidade.

A CAPES, pela bolsa de estudo fornecida.

A todos que me ajudaram a persistir. 
SUMARIO

Página

LISTA DE TABELAS $\ldots \ldots \ldots \ldots \ldots \ldots \ldots \ldots \ldots \ldots \ldots$

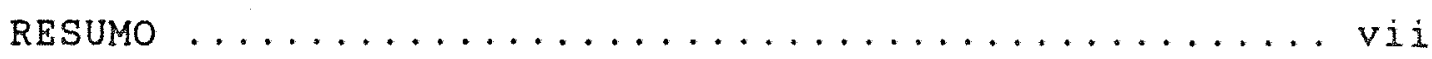

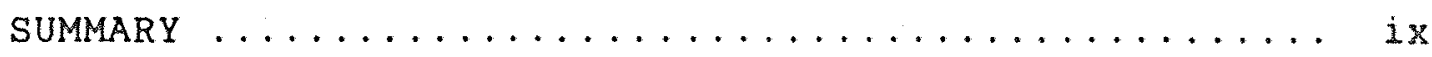

1. O PROBLEMA E OBJETIVOS ................... 1

1.1. Introdução $\ldots \ldots \ldots \ldots \ldots \ldots \ldots \ldots \ldots \ldots \ldots \ldots \ldots$

1.2. Definição do Problema ............... 5

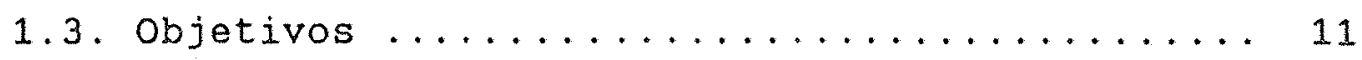

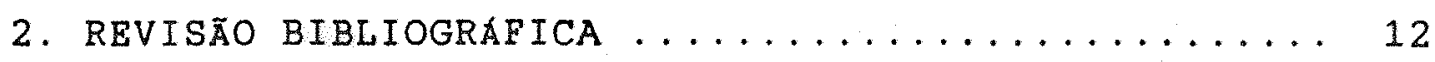

3. METODOLOGIA .......................... 25

3.1. A Empresa Rural .................. 25

3.2. o Modelo de Planejamento .............. 26

3.3. o Modelo de Contabilidade ............. 31

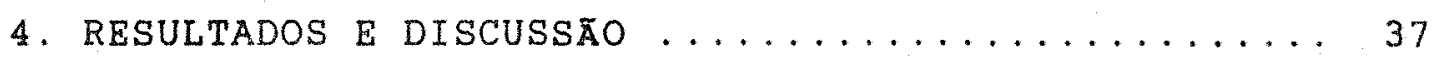

4.1. Análise dos Planos da Emprésa Rural ....... 37

4.2. Fluxo de Caixa .................. 58

4.3. o Plano de Contas ................... 64

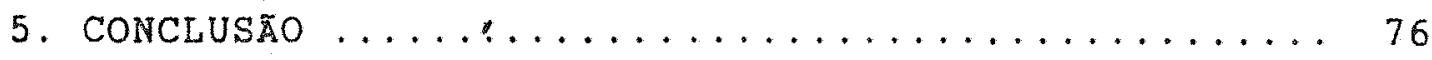

6. REFERENCIAS BIBLIOGRAFICAS ............ 77

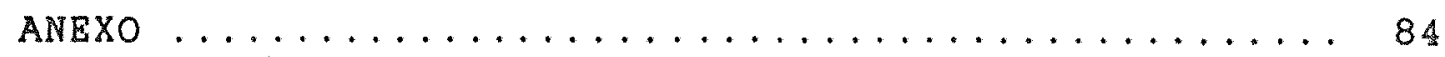




\section{LISTA DE TABBLAS}

página

1. Aroas de Culturas (ha) e Módulos de Criações a Serem Desenvolvidas nos Anos do Horizonte de Planejamento do modelo - Sitação I ........... 39

2. Necessidade de Mão-de-Obra Fixa Comum (M.O.C.) e Mão-de-obra Qualificada (M.O.Q.) nos Anos do Horizonte de Planejamento do modelo - Situação I . 41

3. Necessidade de Horas de Trator de Esteira (HTE) e Trator de Pneu (HTP) e aplicações financeiras por perído do ano no Horizonte de planejamento do modelo - situação I ................... 42

4. Areas de Culturas (ha) e Modulos de Criaços a Serem Desenvolvidas nos Anos do Horizonte de Planejamento do modelo - Sitação II ........... 44

5. Necessidade de Mão-de-Obra Eixa Comum (M.O.C.) e Mão-de-obra Qualificada (M.O.Q.) nos Anos do Horizonte de Planejamento do modelo - Situação II ... 45

6. Hecessidade de Horas de Trator de Bsteira (HTE) $\theta$ Trator de Pneu (HTP) e aplicações financeiras por perído do ano no do Horizonte de Planejamento do modelo - situação II .................. 47

7. Areas de Culturas (ha) e Módulos de Criaçöes a Serem Desenvolvidas nos Anos do Horizonte de Planejamento do modelo - Sitação III ...........48 
Página

8. Necessidade de Mão-de-Obra Fixa Comun (M.O.C.) e Mżo-de-Obra Qualificada (M.O.Q.) nos Anos do Hori zonte de Planejamento do modelo - Situação III ... 49

9. Necessidade de Horas de Trator de Esteira (HTE) $\theta$ Trator de Pneu (HTP) e aplicaçōes financeiras por periodo do ano no do Horizonte de Planejamento do modelo - situação III ................ 51

10. Areas de Culturas (ha) e Modulos de criaçōes a Serem Desenvolvidas nos Anos do Horizonte de Planejamento do modelo - Sitaçăo IV .......... 54

11. Necessidade de Mão-de-Obra Fixa Comum (M.O.C.) e Må-de-Obra Qualificada (M.O.Q.) nos Anos do Horizonte de Planejamento do modelo - Situação IV . . 55

12. Necessidade de Horas de Trator de Esteira (HTE)

e Trator de pneu (HTP) e aplicações financeiras por perído do ano no do Horizonte de Planejamento do modelo - situą̧ão IV ............ 56

13.0 Fluxo de Caixa proposto ..................61

14. Elenco de Contas para Empresa Rural: Fazenda

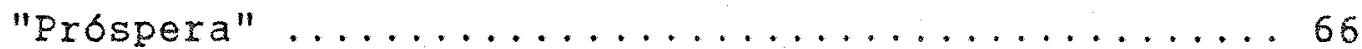

15. Elenco de Contas para Contabilidade Regime de

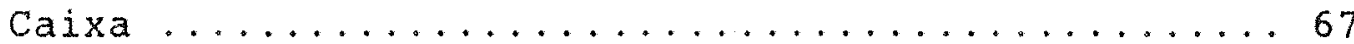




\title{
PLAMEJAMENTO E CONTROLP DE
}

\section{EMPRESA MGROPECOARIA}

\section{On estudo de caso}

\author{
Autora: BLAINB MENDONÇA BERNARDES \\ Orientadora: PROFa DRa ZILDA PABS DE BARROS MATTOS
}

\section{RESUMO}

o propósito deste trabalho é desenvolver um modelo de planejamento para uma empresa rural e um sistema de controle do plano a ser gerado por este modelo. Através da Revisão da Literatura, verificou-se que para as funções de planejamento e controle, intrinsicamente ligadas, não foram desenvolvidos trabalhos considerando-se essa relação entre as funçōes, para empresas rurais. A orçamentação tem sido, provavelmente, o instrumento mais usado no planejamento e algumas vezes um "controle orçamentário" esboça a ligação mencionada acima. Separadamente, são encontrados trabalhos de planejamento para empresas rurais e muito pouco sobre cortrole dessas empresas. Um instrumento que possibilite um tratamento em conjunto dessas funções, não é encontrado.

Neste trabalho, desenvolveu-se um modelo de planejamento multiperiódico utilizando-se Programação 
Linear. Esse modelo projeta um Fluxo de Caixa para o qual foi desenvolvido um Plano de contas que é uma tentativa de fornecer ao produtor um instrumento capaz de controlar o plano fornecido pelo modelo de planejamento.

Controlar o Demonstrativo de Fluxo de Caixa, entretanto, o o mínimo necessario para a boa administração de uma empresa. Após implantado, esse sistema deverá ser ampliado para que o controle financeiro da empresa rural seja possivel. 


\title{
FARM PLANHING MN CONIROA:
}

\section{A CASE STUDY}

\author{
Autho: : RLAINE MENDONCA BERNARDES \\ Advisor: PROFa DRQ ZILDA PABS DB BARROS MATTOS
}

SUMMARY

The purpose of this study was to develop a planning model for a farm and a system to control the plan generated by this model.

It is observed, through the review of literature, that for these two functions (planning and control), which are instrinsically related, there is no reference involving the relationship between them, for farms. Budgeting has been the most used instrument for planning and the "budget control" reflects the above mentioned relation. There have been found references on farm planning and very few references about control. It is not found an instrument that allows a joined treatment of these Eunctions, for farms.

In the present study, a multiperiodic planning model using Linear Programing was developed. This model projects a Cash Flow statement for which an agricultural accounting model was generated. These accounting model, constitute an attempt to give to the 
producer an instrument which is able to control the output of the planing nodel.

The control of the Cash Flow however, is the minimun that one could expect from the businnes administration. Once implemented, this system shall be amplified in order to make possible a more complete financial control of the farm. 
1. O PROBERMA B OBJETIVOS

Neste capitulo serzo apresentadas as funçós de planejamento e controle enfatizando-se o atraso no desenvolvimento dessas funções nas empresas rurais em relação às empresas urbanas. A definição do problema e dos objetivos a serem apresentados será feita em seguida a apresentação de algumas peculiaridades desse setor quo provavelmente teriam levado ao atraso mencionado.

\subsection{IRTRODUÇÃO}

A partir das situações recentes de altas taxas de inflação e inovação tocnologica, e possivel perceber que tornou-se crescente a importancia das funçes de planejamento e controle dentro das empresas. Diante da rapidez de mudanca cecnologica, as emoresas estrangeiras já começaran, há algum tempo, a dar onfase a provisoos de tecnologia em relaça à sua indústria e utilizálas no planejamento. Para koortz et alli (1987), esse interesse foi resultado das mudanças e crescimento econsmico gue, juntamente com oportunidades, geram riscos, particularmente numa epoca de competicão mundial por mercados, recursos a 
influência. De acordo com esses autores, "a tarefa do planejamento e exatamente minimizar riscos, ao nesmo tempo em que tira proveito das oportunidades." No Brasil, o processo não vem sendo diferente nesse sentido. BOUCINHAs (1972), afirmou que o processo de desenvolvimento economico levou à crescente complexidade do sistema economico, modificando profundamente a natureza da atividade gerencial. para ele, o aumento da importancia da funço do planejamento 6 , sem sombra de dúvida, uma das majs importantes alteracöes e decorre do fato de que com o correr do tempo as decisones empresariais pessaram a ser tomadas en condiços de crescento incerteza. Apresentou os seguintes fatores que levaram ao reconhecimento do planejamento como un dos principais elementos do processo administrativo:

Externamente:

a) Elevação da demanda de bens de consumo final. intermediário

b) Aceleraça do processo de inovação, diminuindo o ciclo de vida dos produtos elevando, assim, a incerteza

Internamente, considerou a croscente complexidade da estrutura organica das empresas como a mais importante alteraça. A tendencia à descentralizaço da autoridade 0 da responsabilidade roi apontada como "um indicador palpavel de como as empresas procuraram so adaptar a nova realidade. Pal tondencia contribui significativamente para a elevaço da importancia do desemponho das funcóos do planejamento, coordenagäo controle nos escaloes majs altos 
da Administraçăo de uma empresa." (BovCIMHAs, 1972, pag.2) Planejamento e controle são funcbes que. juntamente com organização e direção resultam numa das definições de administração. Administrar é um processo de planejar, organizar, dirigir e controlar (KENRI FAYOL, Citado por MAXIMIANO, 1988 ).

Várias são as definiçōes para a função planejamento. As três que se seguem também são citaçós de MAXIMIANO (1988):

1) Processo de definix objetivos ou resultados a serem alcancados bem cono as atividades os recursos (meios) que permitirão alcançá-lo.

2) Interferir na realidade, com 0 propósito de passar-se de uma situação conhecida para outra situaça desejada, dentro de um intervalo de tempo pré-determinado.

3) Tomar no presénte decisões que afetam - futuro, visando reduzir sua incerteza.

Para HORTMAN ot al1i (1987), embora haja diferentes definições, "é antes de mais nada, a Eormulaço sistemática de un conjunto de decisoos, devidanente integrado, que expressa os propósitos de un individuo, grupo ou associaça de individuos e condiciona os meios disponiveis para alcançámlos, através do tompo."

o planejamento existe porque os recursos säo escassos o os caminhos a serem seguidos para atingir o (s) objetivo (s) são altomativos. Eatravós do planojamento 
que se quantifica esses recursos a após o estudo das alternativas se escolhe em qual ou quais aplicá-1os. BARNARD e NIX (1973), utilizando-se de principios da economia da produça, mostraram a necessidade de planejar. Desses principios resultaram os elementos do processo de planejamento apontados por esses autores: objetivo, recursos escassos o caminhos alternativos (do uso dos recursos para atingir o (s) objetivo (s).

Para o controle, MAXIMIANO

apresenta as seguintes definiçöes:

1) Processo que visa assegurar a realizaço de um objetivo e identificar a necessidade de alterar esse próprio objetivo.

2) Relacionado ao processo de medir performance, comparar performance medida com padrós estabelecidos no plano a fazer ajustamentos para obter os alvos desejáveis.

Para BOEHJE \& EIDMAN (1984), o processo do controle compreende as etapas:

1) estabelecer padros espocificos aे "persormance" esparada.

2) medir o desempenho roal a compara-10 ao padrão

3) corrigir os desvios dos padrobs dos planos 
na própria definição de controle. Planejamento e controlo estão Iigados pela comparação entre eventos planejados $\theta$ eventos efetivos, ou seja, há uma inter-relaça entre estas Euncõas. Entretanto, na literatura năo tem sido comum encontrar-se meios para se fazer essa ligaço. O que se tem visto são trabalhos tratando de planejamento $\theta$ controlo separadamente ou esboçando uma ligaça.

\subsection{Definicão do Problema}

Serão feitas algumas considerafos sobre - desenvolvimento dossas funcõos nas empresas do secor urbano, o relativo atraso da Administraço Rural comparada a empresa urbana e a situacão atual do sotor agropecuário, con o objetivo de definir e justificar o estudo de un problema na área de planejamento e controle do empresa agropecuaria.

0 sorte interesse pelo planojamento basicamente recente, embora em areas tais como as de operacoses industriais o planejamento da producão tonha recebido enfase há muitos anos. En termos gerais, como uma funço amolamente reconhecida e ativamente oxecutada, o planejamento 6 um fenoneno rolativamente recente (rooñ et a11i, 1987). Pode-se concluir o mesmo com relaça ao controle, una vez gue un dos principais aspectos do planejanemco, de acordo com os mesmos autores, 6 sua primazia - o planejanento precodo a exocuca de todas as 
outras funçöes de administração. As emprosas nacionais, para acompanhar as exigencias do ritmo de desenvolvinento do pais, passaram, ou estao em vias de passar, por una reestruturaça que atinge muitos dos seus setores. Nossas empresas têm-se ressentido da falta de um instrumento capaz de auxilia-las adequadamente na tarefa de gerencianento conforme as novas necessidades (TUNG, 1983).

Se a execução dessas runçơs e recente no sotor urbano, na agricultura 6 ainda incipiente. A agroindústria do álcool - que surgiu e cresceu no contexto de alta inflaço e inovaça tecnologica - parece ter sido pioneira na execugão de tais sunços o provavolnente vem sendo seguida pelas grandes empresas citricolas, que tambem se assemelham bastante às indústrias.

Paralelamente ao desenvolvimento dessas funcoos dentro das proprias empresas, surgixam nos ultimos anos, as "software houses" na tentativa de preancher a lacuna resultante da falta de instrumentos dostinados a auxiliar a execucão de tais funcóos especificamente para a Area rural.

AS possiveis causas da domora no exarcicio dessas funços estäo relacionadas as particularjades desse setor gue o distinguon dos demais no que diz respoito a tomada de decisano. Os setores industrias o comerciais forem levados a desenvolver sistemas de registros complexos que poden ser (e as vezes são) utilizados como instrumontos do controle financeiro e/ou da produga - dopende do cono 6 
feito o registrol que, por sua vez podem ser valiosos no planojamento. Nas empresas agropecuarias, a na obrigatoriedade da apresentaço dos demonstrativos contábeis, embora não tenha sido a causa, foi, possivelmente, um fator que colaborou com o atraso no desenvolvimento de instrumentos de controle para o setor. Deve-se ainda ter em mente que, quando se fala em empresa agropecuária, está se tratando de um conjunto bastante amplo, não de um grupo homogeneo e, consequentemente, nåo podemos esperar que estejam num mesmo nivel de evoluca quanto ao planejamento e controle de suas atividades. Há empresas que não têm registros contábeis, outras os fazen desorganizadamente e algumas, cujos responsáveis tem acesso a empresas de consultoria ou estão acostumados a trabalhax com empresas industriais e/ou comerciais, apresentam modelos bastante complexos. Para esse último caso, as Eirmas de consultoria têm desenvolvido seus modolos baseados om modelos de indústria e comercio.

outras diferenças deven ser levadas en conta. Algumas poden ser decisivas na determinaço do que produzir e guando produzir, una vez gue ossas decisoses esta condicionadas ao tipo de cina, estagos do ano o propria terra. Para a indústria e comercio em geral, ontretanto, esses fatores naturais ou biologicos na condicionam a produço e o planojamento das atividades a seren desenvolvidas, nåo estando, essas empresas, sujeitas a ossa sazonalidade da produgao a do uso de seus rocursos. Anda 
com relaço ao processo produtivo, a outra deciso importante - quantidade a ser produzida - tambem 6 dependente de fatores biológicos que geram a incerteza presente no processo e dificultam o controle da produçáo. Nas empresas urbanas, entretanto, a produça não sendo ao ar livre, pode ser melhor controlada e os riscos são bem menores. A perecividade dos produtos agrícolas 6 uma outra caracteristica que, aliada à estacionalidade da produça e a problemas de armazenamento, determina a estacionalidade da oferta. Esta é outra diferença das empresas rurais quando comparadas aos setores secundário e terciário. (ALBUQURRQUE, 1985, PERES, 1988)

Há ainda os aspectos sócio-economicos. Diferentemente das empresas urbanas, a empresa ruxa enfrenta um mercado altamente competitivo, próximo a competiço perfeita. Entretanco, compra insumos de emprosas gue, em geral, são oligopolistas e multas vezes tamben são poucos os compradores de seus produtos (revendedores, intermediarios ou o proprio governo que muitas vezes 0 único comprador). A situaça se torna ajnda mais complexa por so tratar de produtos com baju elasticidade renda da procura e baixa elasticidade preco da procura. B anda, o associativismo $\theta$ a disponibilidade de infra-estrutura governamental, que tên grande significado para comercio indústria, näo favorecem na mesma intongidade empresas agropecuárias por apresentarem atividades dirusas. No que diz respeito aे cualidade da mão de obra, encontra-se outra 
diserença gritante que, juntamente com o baixo nivel tecnico - administrativo da sociedade rural, traduz-se am dificuldades de adoça de novos processos tecnológicos (ALBUQUERQUE, 1985, PERES, 1988, HOFPMAN @L a11i, 1987). Assim, essas outras caracteristicas cornam singular a empresa agropecuaria e o desenvolvimento de instrumentos administrativos deve observar essas diferengas.

Para estudar de modo mais critico os modelos de planejamento e/ou controle de empresas é fundamental que se temha essas caracteristicas em mente. A obrigatoriedade da apresentacăo dos demonstrativos contabejs - poder de administrar os precos foram, possivelmente, as caracteristicas que nais justificaram o desenvolvimento do controle e planejamento de empresas dos setores secundario e terciário. Na agropecuária, alén de ser dificil chegar-se ao nivel de detalhes oxigidos pelos modelos utilizados nos outros setores, provavelmente teriásido invituol, dadas as diferenças citadas.

Com as recontes muancas de orden Ejscal imolantadas no pafo, acredita-so gue haja un processo semelnante ao ocorrido nas empresas urbanas onde a contabilidade garencial encontrou espago para desenvolver-se provavelnente a partir da contabilidade ficcal existerte. Alom dessas mudangas, o caminho escolnido por algums sotores agricolas visando a diferenciaca de sers produtos -

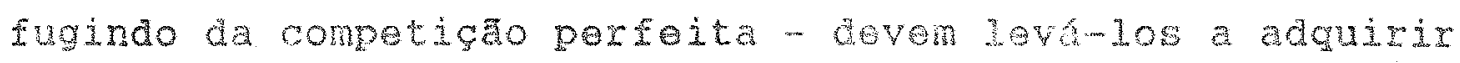
un certo podex sobre os procos de verda. 
esses fatores acentuem o interesse por instrumentos gerenciais.

A baixa demanda das empresas rurais por técnicas administrativas pode ainda ter sido reforgada pela polftica de subsidios dados ao setor a partir do final dos anos sessenta. O Crédito Rural foi o principal instrumento de polftica agrícola no Brasil, a partir de enta. Durante os anos 70, o crédito fortemente subsidiado teve importante papol na modernização da agricultura e, aposar das crlticas associadas a esse instrumento, somente a partir do infeio dos anos 80, com o agravamento da situação econômica do pafs, 6 que surgiram sérios sinais do desgaste do modelo que prevalecia até então, culminando com a retirada de subsidios (MRAUJO \& SHIROTA, 1987; REZENDE, 1982; SANTOS, 1984). AS alternativas apresentadas para o impasse surgido no financiamento das proximas safras voltam-se para a necessidade de o setor se autofinanciar, o que, dentro de um mercado bem mais competitivo que há alguns anos atrás, requer maior eficiencia e consequentemente maior profissionalizagão des agricultores (RODRIGUES, 1987 ; VRIGA, 1988). Isto provavelmente ocorrerá aos poucos, aumentando a demanda das empresas zurais por instrumentos que auxiliom na tomada de decisão.

1.3. osjetivos

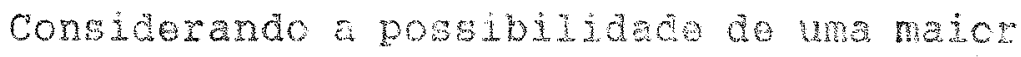


demanda por instrumentos gerenciais, o presente trabano ton por objeivo geral desenvolver um modelo de planejanento e controle de caixa para uma empresa agropecuaria e como objetivos especificos:

a) Eazer um levantamento sobre as principais informaçöes necessárias ao planejamento de uma empresa (estudo de caso);

b) Utilizar essas informacoos Ma construça de um modelo de planejamento usando programagão Linear, de onde será projetado o fluxo bimestral do caixa da empresa.

c) Selecionar as informagos necossásas ao controle do plano a ser gerado pelo modelo de planejamento (produça) e do fluxo de caixa.

d) Desenvolver um sistema de controle do Luxo de caixa.

e) Com base nos objetivos "a" iniciar a organizaço do un sistema contabin yisando interligar o modelo de planejamento ao sistema de controle. 


\section{REVISAO BIBLTOGRAFICA}

Neste item serão discutidos trabalhos que abordaram temas relacionados ao planejamento e controlo destacando-se as técnicas mais utilizadas pelos autoros.

Nas empresas urbanas, o instrumento mais usado no planejamento e controle tem sido a orcamentacado, onde avalia-se custos e retornos das diferentos possibilidades de utilizaço dos recursos. Para TuNG (1983), - orcamento e parte fundamental do planejamento. Do acordo con esse autor, a ênfase das definiçes mutas vezas recaj sobxe os diferentes componontes do oxgamento: para algurs tom carater de "plano financeiro que serve para estumatia - controle do oporagoses Euturas", para outros "procura analisar as possibilidados futuras de atugaro o obtabolece objetivos que a emprese deve estorgar-se para alcangar." Na visão do TUNG, o orgamento consiste, assencialnonto, om un plano de trabalho coordonado e no concrole desse plano. Independante do grau de importancia atribudo a orcamentagăo, ela tem sido assunto praticamente obrigatorio na literatura especifica para a aroa de Aministraço Rural: seja como un topico ou como o pracipal objetivo de um I.vro. Mposar das diforontes fomas do se avaijar custos o 
retornos, nao parece estar nesse aspecto a maior diforenca de pontos de vista e sim na ênfase que se dá ao processo. Por exemplo, para NoronhA (1981), a orgamentação só faz sentido como instrumento auxiliar de planejamento, organização e administração da empresa.

Quanto as principais Iimitaçoses do oxçamento tradicional, BRULL (1983) citou a inclusa do poucas alternativas para a seleça da mais satisfatoria a a adaptaço diffeil para refletir as bruscas mudancas do condições: sua flexibilidade chega até mudanças nas vendas ou produça. A partir dessa visäo, o autor desonvolveu um modelo de planejamento econômico financeiro. Nesse modelo, a administraça de ativos e passivos é vista como un conjunto de variáveis que formam o composto financeiro. O autor optou por construir um modelo de simulaça por considerá-1o mais adequado à situações nais complexas quando comparado a modelos de otimizaçã que necessitariam de informaçōes também complexas que não estariam dispontveis. Alén disso, considera que modelos de simulagão contribuem em todes as etapas do processo decisório.

"O ponto de partida ó conjunto de informaços do ambiente que sao coletadas o, em seguida filtradas pelo tomador de decisäo, gue seleciona aguelas que considera relevantes na soluça do problema en análise. A Eiltragom a escolha das variaveis-chavos a seren usadas no modelo do problema.

Este modelo 6 a base do sistoma preditivo: 
- tomador de decisão pode variar os dados de entrada de modo a pesquisar alternativas, analisando os possiveis eseitos de todos os cursos de aça.

Estas alternativas deven ser avaliadas a partir de objetivos formulados e regras do decisão estabelecidas que levam à seleção de um determinado caminho a seguir. Portanto, como resultado do processo docisorio, temos um plano que e posto em prática. Os resultados desta aço roalimentam o processo, gexando novas informagoos gue chegam ao tomador de decisan (BRULt, 1983, pag. 65).

No modelo desenvolvido por BruLL (1983), a despesa Einanceira e variavel dependente. Atraver de calculos que podem, inclusive, ser foicos manualmente, o modelo prevê a necessidade de caixa no periodo, calcula o endividamento adicional necessáto e reprograma o desencaixe. E um trabalho intexessante, e e posslvel gue possa contribuir para a construça de modolos que envolvam - planejamento da producão, o que, evidontemente, mo eza objetivo do autor, mas tem sido dos estudiosos volvados para a area de planejamento do empresas agricolas.

Ao contrário da posiço adotada polo autor acima, que considerou duvidosa a eficiancia dos modelos de otimizaga, pesquisadores de Bconomia Agraxia o Adninistraģo Rural vem "apostando" nesses modelos, obtendo resultados nuito bons e, principamente, dando inportantes passos para a superacao das initacos nomalmome atriburad a esses modelos. A tecnica de orinizago gue vom 
sendo utilizada no planejamento é a programaca Linear (P.L.). As informações nocessárias para usála sắ semelhantes às utilizadas na orçamentaç afirma que a essencia de ambas as técnicas para problemas de curto prazo são: desenvolver uma alocąå para os recursos Iimitados possuidos para comparar aguela alocacao sucessivamente com alocaços alternativas o selecionar a que maximize o retorno lúquido de caixa. os dados relovantos para cada netodo de produça são: as quantidades necessarias por área dos recursos fixos que restrinjan a oscolna e uma estimativa do retorno Ilquido de caixa por área.

A P.L. já vem sendo usada no planejamento de propriedades agricolas no exterior ha mais de trinta anos - no Brasil, embora existam alguns trabalhos desonvolvidos há mais de vinte, a verdade $e$ que as limitaços, principalmente de ordem computacionais, impediam o avango dessa ténica em Administraço Rurali. Mesmo assim, TEIXEIRA FILHO (1974), considerou os trabalhos de SUGAI E CRISTANCHO como os primeiros em que se utilizou P.L. am Administraço Rural no Brasil. SUGa (1967) tinha por objetivo selecionar os empreandimentos mais lucrativos, estimar os nLvejs de vBo economico recomondados dos recursos, o nivel fe lucro maximo da empresa e os nivis de uso dos recuros, om cada ompreendinento agropecuário do stín de Economia Rura da Universidade federal de Vigosa. Chegou a afimar que a p. . teria as mesnas Iintagoes do motodo dos orgamentos, mas, como foi visto, apesar das limitaços que existiam na 6poca, 
a P.L. sempre possibilitou a escolna entre diversas alternativas. o autor chamou a atenço para o sato do os resultados prenderen-se à determinadas pressuposiços, entro elas a fidedignidades dos coeticientes.

CHAVES (1970), construju um hodelo de P.L. aplicável a um projeto de secagem e armazenamento de grasos. Nesse sentido, a tomada de decisões relacionava-se con os tamanhos economicamente ótimos de lotes de grãos úmidos, com os niveis de estoque na fase de pré-secamento e com a capacidade do secador. Determinou-se a alocaça do tempo do secador, do nivel de estoque de grãos úmidos e a quantidade em cada periodo de tempo. O próprio autor argumentou sobre - que poderia ser apontado como a mais séria restriça (o fato de estar utilizando-se de um modelo deterninfstico para resolver um problema probabilistico).

Nos anos setenta, cresceu a utilizaço da P.L. na area de Economia Agricola. Säo muitos os trabalhos que so utilizaram dela para testar politicas, antre eles: FERREIRA (1971), MESQUTTA (1971) O OLIVRTRA (1971).

Avanços na utilizaca dessa ténica, possibilitaran a incorporaço do risco nos modelos. Esses modelos levaram ao surgimento de uma serie do trabalhos voltados para o desenvolvimento de instrunentos auxiliareș na tomada de decisao e/ou estudos sobre o comportamento do agricultor sob condiços de risco. Tambem rossa fase, os trabalhos na area de Economia Agrária sa mutos. Na Administracăo rural, entretanto, ainda săo poucos. AzEVEDo 
FILHO \& PERES (1986) incorporaram o risco num mocielo de R.L. aplicado a Administração Rural, utilizando-se do modolo desenvolvido por MARKOWIT2 (1956) modificado por HAZELL (1971). Provavelmente esse seja o primeiro trabalno om Administração rural no Brasil que considera explicitamente o risco.

ESTRAVIZ RODRIGUES (1987), ein estudo direcionado especificamente ao planejamento agropecuário apresentou uma revisão dos metodos de inclusão de risco em modelos de P.L. e avaliou a viabilidade de se utilizar a simulaça como forma de incorporaça da aleatoriedade dos coeficientes nos modelos de P.L.. O autor propós um método onde a simulaça e usada para geração de valores amostrais para coeficientes aleatorios presentes no problema de P.L.. Atraves da simulação são gerados valores apropriados para os coeficientes aleatóxios e inclui-se no modelo de P.l. o conjunto formado pela geracão dé um valor para cada coeficiente estocástico, a partir das respectivas distribuiçoes de probabilidades. o processo do simulaça utilizado considerou coeficientes com distribuiço normal, triangular o retangular para a geracão dos valores amostrais. Considerou ainda, para cada distribuiço, diferentes situaçoses de correlação e gerou-se valores amostrais através do método apropriado. Testou a metodologia comparando com os modelos de programação quadrática e MOTAD de inclusão de risco em P.L., utilizando-se de exemplos de aplicaça apresentados por EREUND (1956) e HAZELL (1971). 
Tanto os modelos de orgamentaça guanto os de P.L. São dependentes de coeficientes técnicos e esses seriam obtidos através dos registros da empresa. Com a inclusão da simulação baseada no conhecimento das distribuições de probabilidades às quais se ajustam os coeficientes aleatórios, os modelos de planejamento ficam ainda dependentes do conhecimento próvio dessas distribuições, que a uma questäo contornável. Há ainda a vantagem de se amenizar o problema da imprecisão dos dados obtidos junto as empresas. Embora essa tenha sido uma preocupaça de vários autores, muito pouco parece se ter avançado no sentido de se fornecer dados mais precisos, ou seja, de se organizar sistemas de informaçós voltados para a tomada do decisão.

Apesar das diferenças ontre os tipos de empresas, possivel que a metodologia utilizada por PINTo (1987) para desenvolver um sistema de informaçoos administrativas para uma ompresa do rano da industria o comercio também possa ser útil em empresas rurais quando se considera a propriedade como um sistema. Descreveu a aplicaça da metodologia de SCAICO e a implantação de un sistema microcomputarizado desenvolvido a partir dessa metodologia, onde considera-se o seguinte fluxo:

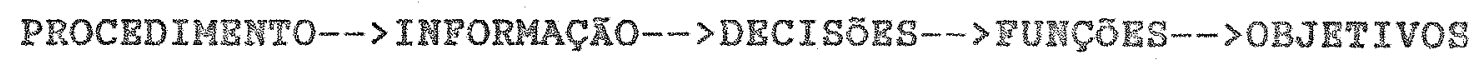

De acordo com esse autor, parte-se dos 
objetivos globais da empresa e chega-so ao estabelecimento dos procedimentos de forma clara, lógica e direta. No estudo de casos, fixou o objetivo económico mais geral da empresa como sendo o de maximizar o retorno sobre os recursos nela empregados, ou seja, a maximização da taxa de retorno sobre - ativo operacional (R.A.O). Entendendo-se Funços como o "conjunto de procedimentos para apoiar decisoes que deverao ser tomadas", para atingir o objetivo acima, elas eram: comprar, vender e produzir. Identificou as decisöes envolvidas no desempenho das funções acima listadas $\theta$ o conjunto de informaçóes necessário para se tomar cada decisão. Reunindo-se os procedimentos conforme a base de dados comum a eles elabora-se os sistemas computarizados. 0 modelo de planejamento necessitaria de mais informaçőes. Depois se desenvolveria um sistema integrado, que compreendesse a relacionasse todos os dados da empresa fornesse relatórios necossarios a àministraça.

Principalmente para o caso das curesas rurais brasiledras, de acordo com OLIVEIRA FLLHO (1989), um sistema de informaçes pode modificar o orientar atitudes fortemente arraigadas que, inclusive, impedem a modernizaça da emprosa agrícola.

A empresa demanda informaços que proveon da própria empresa como do meio ambiente em que egtá inserida. Estas informaços (econômicas inclusive), devem pormitir a empresa idontificar ate que ponto problomas que afetam a renda a produtividade poden ser resolvidos a 
partir de outras soluções, que não somente a mexa adoça do tecnologias. Nesse caso, as informações consideradas devem ser relevantes para a análise e planejamento de suas açós. Estes instrumentos devem, por sua vez, ser compostos de técnicas e métodos, e a adoção dos mesmos depende de adequações com a realidade prática do empresário (OLIVRIRA FILHo, 1989). Estudando os sistemas de informação e o processo de transmissão dessa às empresas rurais pela CEPLAC, esse autor considerou indispensável a utilização da informatica cono instrumento para alcancar a rapidez e precisão exigidas. Propôs um instrumento que permite "realizar de modo preciso, rápido e oportuno, as tarefas de avaliação de decisones de custejo e investimentos en culturas perenes." Consiste em planilhas de cálculo de orçamentos anuais de custos e receitas, cálculo do custo anualizado equivalente de produçăo, indicadores de rontabilidade de novos invostimentos e cálculo da capacidade de pagamento.

Também com essa preocupaça com o uso da informatica, surgiu o Projeto "Aplicaços de Microcomputador pola extons Ro Rural no Assistencia ao Agricultor." Envolvendo o uso de planilhas eletronicas, os "software" szo basoados om perguntas que o produtor responde de acordo com dados reais - se elo tiver algum sistema de registros - ou con dados qu form memorizados ou estimados por ele. bem prováve: que con a divulgacaio de "software" despe tipo, os produtores comecen a adquirir o hábito de armazenar dados gue sorko expenamente uteis na obconga de coeficientes 
técnicos, que por sua vez, "realimentariam" modelos de planejamento.

- uso adequado do computador pode facilitar e melhorar o desempento de uma ompresa, possibilitando o desenvolvimento de modelos incorporando risco o agilizando o controle dos planos. Deve-se dar atença espocial às informaçöes que são de fato rolovantes e näo se incorrer no erro frequente de se dispendex recursos para obter e trabalhar com informaçōes que fornecem pouco retorno. Nesse sentido, há artigos e até livros sendo publicados no exterior visando, inclusive, a auxiliax o produtor na decisão sobre a compra ou não de um microcomputador. WILSON \& MACPHERSON (1982) publicaram um desses livros onde discutem como decidir se um computador $\theta$ necessário, o que ele pode fazer, escolha de "hardware", "software" (há um guia para agricultura e horticultura), etc. PATERSON (1982) tambern escrevè dentro desses moldes, oxaminando o cue os microcomputadores poden fazer na fazenda (administraçăo de rebanho, raça mais adequada, informagao mais exata o oportune sobre fluxo de caixa, retornos, etc). HARDARER et al1i (1981), afirmam que os sistemas de registros rurais falham porque não satisfazon ab necessidades da maioria dos agricultores. No futuro esses sistemas devera estudar os objetivos, comportamento atitudes na tomada de decisão dos fazendoiros "médios". Pera eles, tais estudos com apenas algumas simples mudanças, merecem ser fomentados. Mudanças especisicamento con relaça 
a registros contábeis tambom são estudadas por JoNEs ot aldi. (1982). De acordo com esses últimos, essas alterações so fazem necessárias dadas às necessidades insatisfeitas de seus usuários. Lembram que a contabilidade é a principal fonte de dados para avaliar o desempenho economico das fazendas.

Além de permitir uma avaliaça da empresa no tempo, a contabilidade é a fonte principal de dados para - cálculo do imposto de renda a pagar $\theta$ de indices de desempenho ("performance") de interesse para a empresa. Estes últimos são comparados aos indices de desempenho planejados, o que permite a identificaça de desvios e de açōes corretivas a serem implantadas quando necessárias.

Para que o controle seja possivel, entretanto, ́́ preciso que o sistema de dados a serem coletados seja desenvolvido de maneira a permitir a geraça dos mesmos indices de desempeñho estabelecidos no planejamento.

Dentre os sistemas de controle que podem ser implantados na empres rural, ofinanceiro se coloca como um dos mais importantes. En sistemas de contabilidade para empresas rurais americanas, frequentemente são inclufdas Contas de Receitas e Despesas, Demostrativos de Resultados do Exerclcio (DRE), Balango Patrimonial (BP), Demostrativo de Fluxo de Caixa (FC), Contas a Pagar a a Receber o Contas dos Empreendimentos. O DRE, BR e FC Ea de major interesso ao planejamento. O propósito do DRE c determinar o fluxo de 
resultado gerado pela empresa ao longo do periodo. I geralmente calculado anualmente para nodir a lucratividado ao longo do ano que passou, entretanto, pode ser completado mensalmente, trimes-tralmete, semestralmente ou outro perlodo se for útil para propósitos administrativos. (BOEHJE \& EIDMAN, 1984).

- Demostrativo de Fluxo de Caixa é indispensável para o controle financeiro da empresa agropecuária ser efetivo uma vez que para que isso ocorra, é necessário um conhecimento minucioso das fontes e usos de caixa da empresa. Este demonstrativo resume as transaçoses do caixa da empresa durante um dado periodo de tempo tal como um mês, um trimestre ou ano. Através dele, problemas potenciais podem ser detectados durante o ano entao as correçöes podem ser feitas. Se um administrador mantiver somente um DRE e BP anuais como principais componentes do controlo financeiro, problemas que podem ter serias consequências não serão detectados até o final do ano. Com - fim do ano, as perdas já poderão ser significativas e as medidas corretivas dificeis ou mesmo impossiveis de serem implementadas. O FC fornoce o sistema mais oportuno para monitorar as condições financeiras da firma e detectar problemas potenciais. (BOEHJE \& BIDMAN, 1984).

No Brasil, há sérios problemas no uso da contabilidado como instrumento gerencial. Do acordo com FRANCO JR (1984), há inadequação dos sistemas de escrituração e contabilidade - as adaptaçoses não levaram em 
consideraça as peculiaridades do setor rural do pais. A utilizaça de modelos importados ou adaptados de outros setores para a agricultura vem sendo apontada como uma das causas da pouca aceitação da contabilidade agricola disponfvel. FRARCO JR (1984), buscou e encontrou evidencias historicas para confirmação desta hipótese. O mesmo autor, citando RODRIGUES DA CRUZ (1983), tambén chamou a atonça para o desenvolvimento da micro-informatica no pass como um novo componente agindo no setor agropocuário.

os trabalhos envolvendo registros agricolas parecem concordar com a necossidado de direcioná-los a auxiliar na tomada de decisao. por outro lado, já parecem clássicas as criticas a aplicabilidade de modelos de planejamento devido à dificuldade de se obter dados confiáveis para "alimentar" esses modelos. Nobto trabalho, pretende-se desenvolver um modelo de planejamento multiperiódico que permita a projeçäo do un Elusso de caisa. Através da comparaça deste demonstrativo com o fluxo de caixa real obtido de um sistema de registros a sor desenvolvido será possivel se fazer o controle do plano obtendo-se os coeficientes padröes para a "realimentą̧a" do modelo de planojamento. 


\section{METODOLOGIA}

Tratando-se de un estudo de caso, primeiramente será apresentada a propriedade em questao. Em seguida, as metodologias utilizadas no desenvolvimento dos modelos de planejamento e contabilidade. Sendo a técnica utilizada no planejamento já bastante conhecida (P. ̌.), neste captulo não se pretende discuti-1a e sim apresentar o modelo especifico do P.L. utilizado, ou seja, a formulação geral e a definição das variáveis, detendome apanas nas particularidades deste. Quanto ao modelo de contabilidade, há necessidade de definição de alguns conceitos. Estas definiçós serå foitas à medida que se apresentar o sistema.

3.1. A Rmpresa RuraI

Localizada na regiao de campinas-sp, possui 138,68 ha, dos quais apenas 38 são mecanizavois e 6 hectares sao de várzea. Apesar das caracteristicas topograficas dosfavoráveis, fol mantida por muitos anos com café. Ultimamente essa cultura vinha sendo abandonada - na se apresentava como una alternativa viável dados a baixa 
produtividade $\theta$ preços obtidos. Com o abandono do cafe, a ma-de-obra fixa (vinte familias) vinha se ocupando de atividades de manutençåo da empresa e culturas de subsistência. Os donos, proprietários urbanos, herdaram a fazenda recentemente e querem mantê-la com a renda máxima possivel (ou um minimo de perdas). Para isso, dispuseram-se a equipar a propriedade com o que fosse necessário para novas atividades e fazer alterações de ordem administrativa (implantação de um sistema contábil, por exemplo).

\subsection{O Modelo de Planejamento}

Feitas algumas visitas fazenda nas quais se fez um inventário da propriedade e de posse de un levantamento de subclasses de capacidade de uso do solo (ANEXO), foram levantadas algumas alternativas visando a utilização dos recursos aisponiveís. A área relativamente pequena da propriedade fez prevalecer a idéla de gue alguns produtos a serem escolhidos deveriam possibilitar uma integracão, de forma que pudessem "escapar" do mercado de concorrencia perfeita (se possivel permitindo inclusive a comercializaçăo de uma marca própria, considerando-so a proximidade dos grandes centros consumidores). Apos alguns estudos preliminares, algumas alternativas foram colocadas em um modelo de programaço Linear (P.L.). 
A formulaca goral do probloma:

$$
\text { Maximizar } z=\sum_{j=1}^{n} c_{j}^{x}{ }^{n} \quad(j=1,2, \ldots n)
$$
a $x<x$
$i j$ ij i

Neste caso, a Funga objetivo $(\mathrm{R} .0)$ "z"

mede o retorno aos fatores fixos. As atividades $x_{i j}$ sa culturas, criações, aplicaçöes de recuræos no mercado financeiro, transferências de receitas entre binestres e custos (ma-de-obra e tratores). Os custos de insumos utilizados nas atividades sa deduzicos nos respectivos coeficientes - $c_{j}$ - que correspondem, portanto, ds receitas brutas das atividades menos custos de insumos. Os outros custos variáveis a de mão de obra, combustuveis e lubrificantes - entram na funça objetivo (atividades cujos coeficientos sao negativos).

Trata-se de um modelo dingmico, onde 0 primeiro ano apresenta a seguinte estrutura:

$$
\text { Atividades: }
$$

9 atividades para seringueira (correspondendo às diferentes idades da cultura do plantio a estabilidade). 
9 atividades para cana-do-acúcar lo plantio a resorma)

2 atividades para investimento na área animal (para confinamento de bovinos e instalaço de viveiros para criaça de camarão)

1 atividade de engorda de bovinos en regine de confinamento

1 atividade de criagão de camarko

6 atividades para frango (uma para cada bimestre)

1 atividade para capacidade instalada para criaca co frangos

1. atividade para cultura de subsistencia

1 atividade para ma-de-obra comum fiza

1 atividade para mä-de-obra gualificada fixa (tratorista, pedreiro)

6 atividados para horas totais trabalhedas com tracor de esteira (una por bimestre)

6 atividades para horas totais trabalnadas com tratores de pneu (uma por bimostre)

6 atividades para aplicaços de rocursos no mercado Einanceiro (una por bimestre)

6 atividades para transferencia do roceitae ontro bimestees

Restrigos (RHS - "right hand side"):

Restricoes de solo (3): 89 ha näo mecanizavezs 38 ha mecanizutio

6 ha sujaitos inundega 
A fin de se possinilstar un controlo posterior, as quantidades de horas nápuinas, mo de obra disponibilidade de caixa foram divididas por binestre, en:

6 restriçes de horas máquinas (tzatores de pneu)

6 restriços de horas máquinas (trator de esteira)

6 restrigon de ma-de-obra gualiticada fira (tratorista, pedreiro)

6 restriçes de mâ-de-obra comum fixa

6 restricos de saldas de caixa - que corresponden ds safdas, on dinheiro, com insumos, näo-do-obra, horas trabalhadas com tratores, implementos, equipamentos o aplicaço no mercado financejro.

6 restriços para as entradas we cana - recoitas provenientos das vendas dos produtos agropecuarios o de resgato de aplicaços inanceiras

Outras restriços:

1 restriço de nutricão de bovinos com cana (numero de cabeças por área de cana)

2 restrigoes initando os investimentos: criou-se una unidade "modulo" para ser utilizada nessas restrigos. Para - investimento em confinamento, um nodulo representa as instalaços necessarias para a engorda de ate soo cabegas. Para o investimento em camara, 1 modulo equivale a 1,2 hectares que, de acordo con especialistas, seria uma drea minima para uma criaça conercial e vivel economicanente.

1 restrigero gue Iinita a cracko do framgos pola

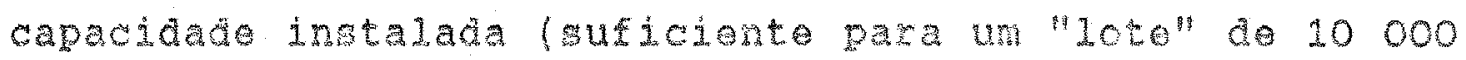


Erangos).

Restriços que limitem as atividados dos prominos anos às beas plantadas ou a capacidade instalada nosses primeiros anos: 3 a 9 para seringueira, 9 para cara, 1 para bovino e 1 para camara $\theta$ ainda a restraga de engorca de bovinos relacionada à área de cana-de-acúar

Os cinco anos seguintes direrem do primeiro por apresentaren as disponibilidades do recursos agregadas por quadrimestre, reduzindo con isso o numero de restriços. Nä apresentam a atividade de capacidade instalada para criaça de frangos, ficando a criaga om todos os anos Iimitada a instalaca oxistento no primoiro ano.

As restriços que se seguem a esses sejs primeiros anos aponas fazem uma ligacajo entre o sexto $\theta$ ano de produção estável - quando as culturas o atividades zootécnicas ostarão estabilizadas. Nesse "bloco" (do setino ao decimo terceiro ano), perde-se o carter dinamico do modelo as atividados cradas para esse persodo tsm como coeficiontes na funga objotivo os respectivos valoros preantes do fluxo l1quido obtido nesso per1odo. Näo há mess atividades de plantio e investimento. As restrigos a apenas as relacionadas as capacidados ja instaladas, restrigos cuanto a disponibilidade de drea por úpo de solo, nutrigo de bovinos e aguelas cus "transteren" as atividaces anteriores para atividaces ostaveis no "Ano ख⿱ 
No "Ano Estáve1", também não há atividades de investimento e plantio, apenas as seguintes variáveis: 2 para cana-de-açúcar - estável e reforma ., 6 para frango (uma para cada bimestre) idem para horas totais trabalhadas com trator de esteira e de pneus e uma para cada alternativa: seringueira, camarão, engorda de bovinos, café e cultura de subsistência. As restrições quanto ao tipo de solo, máquina, mão-de-obra qualificada, mão-de-obra comum, entrada e salda de caixa, alimentação de bovino com cana, capacidade de criação de camarão e de engorda de bovinos. A criação de frangos continua limitada pela capacidado já instalada anteriormente. Há uma restrição exclusiva deste ano que limita a área de reforma de cana em quinze por cento da área com cana em produção.

Da forma como foi estruturado o modelo, os seis primeiros anos podem ser considerados anos de investimento. Através de mudanças no RHS, é possivel utilizá-1o como se o próximo ano a ser planejado sempre fosse o primeiro ano de um plano e ainda obter diferentes planos a serem escomidos para a implantaça.

\subsection{Modelo de Contabilidade}

Para se desenvolver un sistema contabil para uma determinada empresa, e preciso definir seus componentes, os quais serão discutidos a seguir. 
a) Informaços a serem geradas

Como foi dito anteriormente, para que o controle financeiro possa ser efetivamente implantado, é preciso que as informações geradas pelo sistema contábil sejam compativeis com aquelas geradas no planejamento. Neste estudo de caso tais informações serão representadas pelo Demonstrativo de Fluxo de Caixa.

Do modelo de planejamento desenvolvido, pode-se projetar o FC da empresa bimestralmente para o ano agricola seguinte. De acordo com BOEHJE \& EIDMAN (1984), o FC o o componente chave do sistema de controle. Para ser. útil, o sistema deve monitorar o desempenho frequentemente, de forma que desvios com relação aos planos possam ser detectados e os ajustamentos sejam feitos antes de ocorrexem consequências desastrosas.

"A estrutura geral do Fluxo de Caixa parte da identidade:

\section{TOTAL DE FONPES = TOTAL DE USOS \\ DE RECURSOS DE RECURSOS}

onde as Fontes de Recursos são reprosentadas pelas Disponibilidades iniciais do periodo, as entradas do dinheiro provenientes da operação da empresa, novas dividas contrafdas" e retiradas das aplicaços no mercado financeiro, pelas empresas, ao longo do periodo. "Já os Usos de Recursos referem-se às saldas de dinheiro pela operaça 
da empresa, (incluindo retiradas do proprietário para gastos com a familia) ${ }^{1}$, pagamentos de dividas, aplicaçōes no mercado financeiro e disponibilidades finais da empresa no período. (SANTOS, 1991, pag. 41)".

o Fluxo de Caisa projetado no modelo é uma estimativa dos usos e fontes de caixa para cada bimestre. Sua estrutura apresenta algumas diferenças em relação as tradicionalmente encontradas na literatura. A principal delas é a apresentação das fontes e usos dos recursos por empreendimento agropecuário. Essa estrutura é o resultado da questäo a ser respondida pelo planejamento londe alocar os recursos, quais as melhores alternativas). Um Eluxo de Caixa Historico armazenará fontes e usos de caixa reais e fornecerá o mecanismo para o contínuo monitoramento da "performance" da firma. Em função da necessidade de comparação com o planejado, a estrutura desse Fluxo de Caixa Historico será semelhante à do projétado: entradas e saidas de caixa distribuidas entre as diferentes atividades agropecuárias. Assim, será posslvel a comparação entre as receitas projetadas e realizadas individualmente polas culturas, criaçoses e provenientes do rosgate de aplicaçós financeiras. Entre as saldas de caixa a comparaço a mais diffcil, mas o modelo a permitirá nos seguintes itens: -mão de obra permanente qualificada, .mão-de-obra permanente comum,

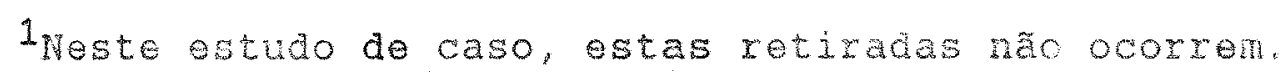


-gastos con trator de esteira (combustiveis o

lubriticantes),

-gastos com tratores de preu (combustiveis e

Iubrificantes),

compra de animais, alimentaça animal, medicamentos a vacinas para animal,

. corretivos, fertilizantes, defensifos, sementes o mudas. Comparando-se as projeços de sontes e usos com aqueles que estejam sendo obtidos, as diferencas significativas se existirem ainda sera percebidas a tempo de serem corrigidas antes que maiores problemas possam ocorrer.

\section{b) Lançamentos}

Lançamento e a forma convencional de se registrar as operaçōes de uma empresa. são dois os metodos para se fazer lançamentos:

a) Método das partidas simples: contabiliza-se apenas um debito ou apenas un credito para una dada operação;

b) Método das partidas Dobradas: para qualquer operação há um débito e um crédito de igual valor ou un debito (ou mais débitos) de valom idontico a um crédito (ou mais creditos).

o método escolnido sol o de partidab Simples, exatamente pela major faciuidade na aplicaca. o 
metodo de Partidas Dobradas necessitaria un maior treinamento do pessoal responsável pela escrituraça, o que poderia comprometer a implantação do sistema, considerandose que já serão muitas as modificações implantadas na propriedade num curto espaço de tempo.

\section{c) Livros Contábeis}

Os lançamentos são escriturados em livros contábeis, que basicamente são dois: Razão e Diário.

Razão: consiste no agrupamento de valores de contas de mesma natureza e de forma racional. Em orden cronologica, resume todas as variações sofridas por cada una das contas da empresa.

Diário: é um livro especialmente cronologico que registra todos os fatos administrativos da empresa, em ordem de dia, mês e ano. Deve conter, além da data, o nome da conta a ser debitada o nome da conta a ser creditada (quando se adota o Método de Partidas Dobradas) o historico. Este deve conter aponas o nome do cocumento, sua espécie e nome da pessoa com quem se realizou a operaga. apenas relacionando o registro no livro e documento que comprova a legitimidade das operaços realizadas.

\section{d) Plano de Contas}

E a ordenação, uma estruturação sistematizada das contas utilizáveis na entidade. Contén as diretrizes que orientam o modo de serem feitos os registros, 
estabelecendo a conduta a ser adotada na escrituraça dos fatos ocorridos numa empresa. Deve ser flexivel, permitindo que se introduzam ou que se eliminem contas durante o exercicio, sem prejuizo da sua estrutura básica.

Será adotado um sistema de condificaf̧ões das contas, onde se atribui um número a cada uma delas. Os grandes grupos são: Fontes e Usos de Recursos.

\section{e) Inflaça e Sistema Contálais}

Algumas medidas práticas foram tomadas para se tentar reduzir os efeitos distorsivos da inflaça sobre o relatório contábel. A Lei prevê correção monetáxia para O Ativo Permamente e Patrimonio Liquido. Com isso, o que ocorre é que para fins gerenciais esses relatórios tornam-se ineficazes, por apresentarem alguns valores históricos e outros corregidos.

Uma forma de se contornar melhor esse problema é trabalhar com valores reais para todos os ftens do FC, utilizando-se como deflatores indices de preços ou transformando os valores nominais en dólares. Neste trabalho, pretende-se utilizar esta última altornativa, por considerá-la mais adequada às finaliỏades gorenciais. 


\section{RESULTADOS B DISCUSSAO}

\subsection{Análise dos Planos da Rmpresa Rural}

Serão apresentados resultados obtidos na resolução do problema de otimização dos recursos da Empresa para situaçōes geradas através de mudanças nos limites das restrições ("RHS") da matriz apresentada. Em seguida, serão feitas considerações com base no "preço sombra" lou custo marginal) de algumas atividades e restriçóes.

\section{a) Situação I:}

Neste caso," considerou-se uma disponibilidade inicial de caixa de u $300.000,00$ no primeiro bimestre do primeiro ano. Os investimentos necessários para a engorda de bovinos em regime de confinamento seriam feitos, obrigatoriamente, no primeiro $\theta$ no terceiro anos. Os investimentos para engorda de Camaräo foram limitados em cinco modulos no total, sendo, no primeiro ano no máximo igual a um módulo. A disponi-bilidade de caisa no primeiro bimestre do ano estável seria de us $150.000,00$.

A area maxina do seringueira a ser 
plantada no primeiro ano foi limitada em quinze hectares a área de cana-de-açúcar em dez hectares. Pretendia-se com isso gerar uma situąão bastante próxima a realidade na qual os produtores, no início da implantação do plano, estariam ainda "aprendendo a trabalnar" com essas culturas. A partir do segundo ano, esses limites deixam de existir, ou seja, considera-se a área total não mecanizável disponfvel para a seringueira e trinta e três hectares para cana-de-açúcar (dos trinta e oito mecanizáveis) como os fatores realmente Iimitantes. Nessa "situação I", a atividade engorda de camarão não concorre em área com a cana-de-açúcar.

Na Tabela 1, são apresentadas as atividades agropecuárias a serem desenvolvidas pela Empresa ao longo do horizonte de planejamento. Essas atividades, para facilitar a apresentação dos resultados, foram separadas em Investimentos e Culturas e Criacóes em produção. As culturas säo apresentadas por área $\theta$ as criaçöes e seus respectivos investimentos, por unidade "modulo".

Os resultados mostram que as culturas, no primeiro ano, seriam plantadas ate o limite estabolecido. A seringueira, no segundo ano, já seria plantada em todo o seu limite de area disponfvel, enquanto o plantio de cana-de-açúcar seria feito "parceladamente". Através da análise dos "precos sombra", verifica-se que a entrada de uma unidade da variável plantio de seringueira 
Pabala 1. hreas de Culturas (ba) e Módulos de Criaçoes a searen Desenvolvidas nos nnos do Borizonte de Planejanento do audelo - Sitação I

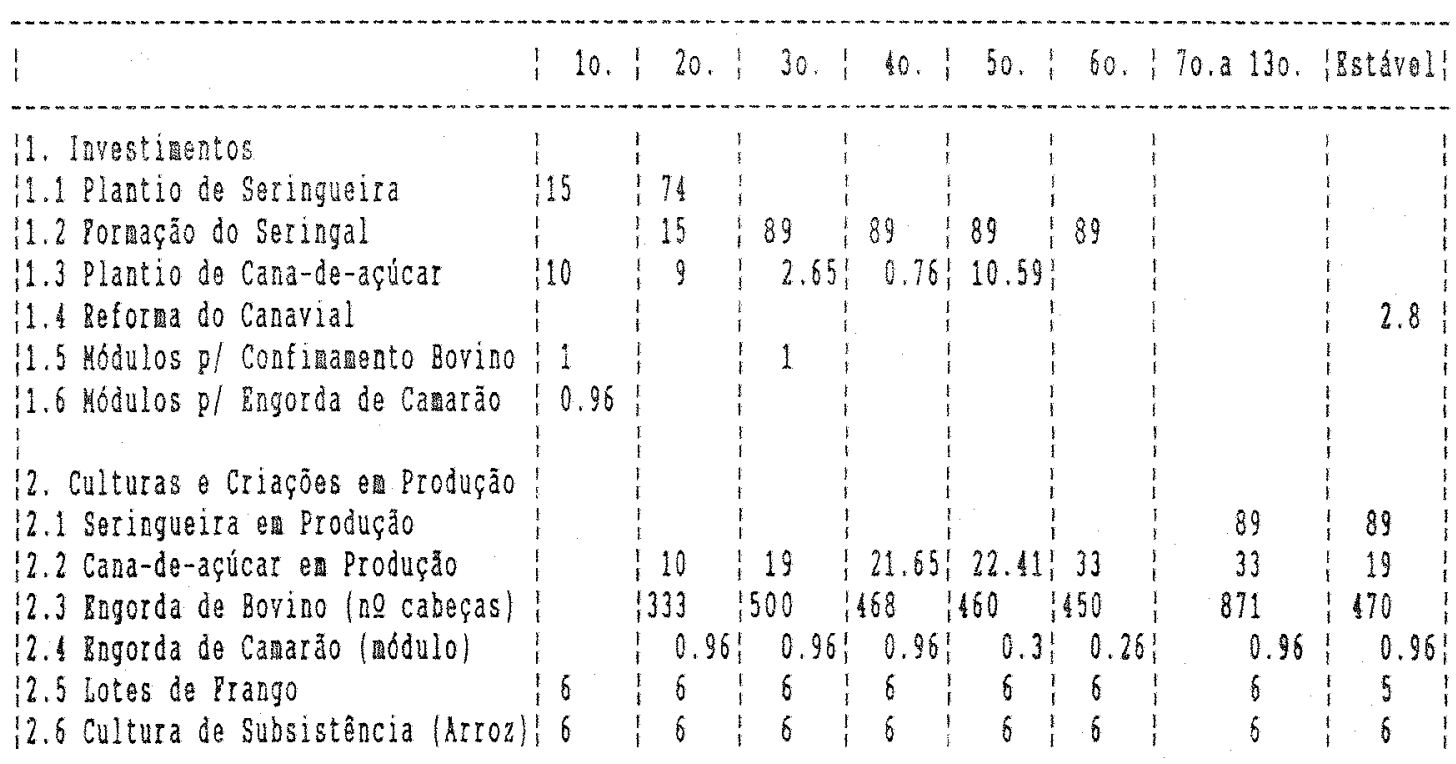

no quarto ano provocaria uma redução na Função objetivo de U\$ 925,80 (tudo 0 mais constante). O plantio da mesma cultura, se fosse feito no quinto ano provocaria uma redução ainda maior ( $\Psi \$ 1316,13$ ). O mesmo tipo de análise feita para a cana-de-açúcar mostra que a redução provocada pela introduço da variável plantio de cana-de-açúcar no quinto ano seria de $\mathrm{\$} \$ 100,66$.

Com relação aos investime.stos na área animal, para camarão deve ser feito no primeiro ano e não deve ser feito no segundo ano. A análise do "preço sombra" fornece a informação para o caso de ser feito o investimento em camara: a Função objetivo sofreria uma reduça de us 1051,33 para este investimento no terceiro ano (a nå no 
quarto) e U\$4 108,11 para o mesmo tipo de investimento no quarto ano (e não no terceiro). Quanto ao investimento em confinamento (instalaçōes, equipamentos), se a variável correspondente for "forcada" a entrar na soluça no segundo ano, provocará uma redução de U\$ 2219,16. Para cada unidado da variável investimento em confinamento no quarto ano, a redução na Função Objetivo será de U\$8461,17. Aplicando-se os mesmos conceitos, as reduçöes seriam de U\$ 7282,87 e U\$ 5963,12, respectivamente para a entrada das variaveis de confinamento do quinto e sexto anos.

Além dessas atividades de investimento, a atividade de produção de frango no segundo bimestre do ano estável também não está na solução ótima. Para um lote de frango, produzido nesse bimestre, a Eunção objetivo se reduziria em $U \$ 272,23$.

Como já foi explicado no capitulo anterior, mão-de-obra e máquinas não funcionam como restriçōes "efetivas". Säo variáveis do modelo cujos resultados encontram-se nas Tabelas 2 e 3 . Essas variáveis têm efeito sobre as restriçöes de salda do caixa. Sendo assim, a partir de agora seräo discutidos os fatores realmente limitantes do modelo: área disponivel, limites de plantio, capacidade instalada (criagão de frangos) ou a instalar (camaråo) e necessidade de cana-de-acúcar para nutrigäo de bovinos.

Para a área de "solo 3", não há necessidade de se detalhar os resultados, devendo apenas ser lembrado que 
trata-se da area de varzea - destinada totalmente a cultura de subsistência que retira dinheiro do caixa para

Tabela 2. Necessidade de Mão-de-obra Fixa Comum (M.O.C.) Mão-de-obra Qualificada (M.O.Q.) nos Anos do do Horizonte de Planejamento do modeloSituação II

\begin{tabular}{|c|c|c|c|c|c|}
\hline \multirow{2}{*}{ Ano } & \multicolumn{2}{|c|}{1} & \multicolumn{2}{|c|}{ Ne de homens } & \\
\hline & 1 & M.O.C. & 1 & M.O.Q. & I \\
\hline 10 . & 1 & 4.56 & i & 1.27 & 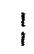 \\
\hline 20 & 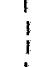 & 19.04 & 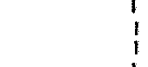 & 3.22 & \\
\hline 30. & 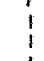 & 24.5 & 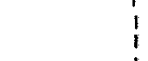 & 2.88 & 1 \\
\hline 40 & 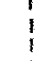 & 22.3 & 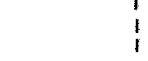 & 1.28 & $i$ \\
\hline 50. & 1 & 15.4 & i & 1.3 & 1 \\
\hline 60. & 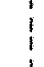 & 15.9 & 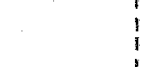 & 1.7 & 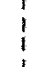 \\
\hline Estável & 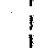 & 8.4 & $\therefore$ & 2.7 & \\
\hline
\end{tabular}

insumos, mão-de-obra e horas de trator. Já o "Bolo 1", se apresentasse um hectare a mais no segundo ano elevaria a F.O. em U 845,76 (neste ano a seringuejra já é plantada em toda a área). No quarto ano, para un hectare deste solo disponfvel a mais, o aumento na F.O. seria de U\$159,88, o maior aumento por unidade de "solo 1 " acrescentado ocorreria se essa unidade estivesse disponivel no sexto ano: U\$ 1862,75. Para o "solo 2", dentro do mesmo raciocinio, os valores seriam: U\$ 37,29 para o sexto U 2508,57 para o 
perlodo do sétimo ao décimo terceiro. Alteraço mais simples que aumentar a área disponivel

Tabela 3. Necessidade de Horas de Trator de Esteira (HTE) e Trator de pneu (HTP) e aplicaçoses financeiras por periodo do ano no Horizonte de planejamento do modelo - Situação I

\begin{tabular}{|c|c|c|c|c|}
\hline Ano & Periodo & HTE & HTP & $\begin{array}{c}\text { Aplicacao } \\
\text { (U\$) }\end{array}$ \\
\hline 10. & $\begin{array}{l}\text { Jul-Ago } \\
\text { Set-Out } \\
\text { Nov-Dez } \\
\text { Jan-Fev } \\
\text { Mar-Abr } \\
\text { Mai-Jun }\end{array}$ & $\begin{array}{l}48 \\
67.5 \\
30.56\end{array}$ & $\begin{array}{l}105 \\
380.7 \\
84.4 \\
7.5 \\
7.5\end{array}$ & $\begin{array}{l}298412 \\
291955 \\
272003 \\
272431 \\
270735 \\
264190\end{array}$ \\
\hline 20 & $\begin{array}{l}\text { Jul-Out } \\
\text { Nov-Fev } \\
\text { Mar-Jun }\end{array}$ & 569.8 & $\begin{array}{c}2369.5 \\
423.3 \\
44.5\end{array}$ & $\begin{array}{r}133551 \\
62837 \\
17056\end{array}$ \\
\hline 30 & $\begin{array}{l}\text { Jul-Out } \\
\text { Nov-Fev } \\
\text { Mar-Jun }\end{array}$ & & $\begin{array}{r}2027.7 \\
49.3 \\
44.5\end{array}$ & $\begin{array}{r}18831 \\
4706 \\
153593\end{array}$ \\
\hline 40 & $\begin{array}{l}\text { Jul-Out } \\
\text { Nov-Fev } \\
\text { Mar-Jun }\end{array}$ & & $\begin{array}{r}1849.8 \\
51.9 \\
48.3\end{array}$ & $\begin{array}{r}13315 \\
146883\end{array}$ \\
\hline 50 & $\begin{array}{l}\text { Jul-Out } \\
\text { Nov-Fev } \\
\text { Mar-Jun }\end{array}$ & & $\begin{array}{r}1805.7 \\
69.9 \\
66.7\end{array}$ & $\begin{array}{r}11887 \\
145522\end{array}$ \\
\hline 60 & $\begin{array}{l}\text { Jul-Out } \\
\text { Nov-Fev } \\
\text { Mar-Jun }\end{array}$ & & 2102.6 & $\begin{array}{r}11887 \\
142955\end{array}$ \\
\hline Estável & $\begin{array}{l}\text { Jul-Ago } \\
\text { Set-Out } \\
\text { Nov-Dez } \\
\text { Jan-Fev } \\
\text { Mar-Abr } \\
\text { Mai-Jun }\end{array}$ & $\begin{array}{l}35.6 \\
64.9\end{array}$ & $\begin{array}{l}939.19 \\
960.4 \\
116.2 \\
111.2\end{array}$ & $\begin{array}{r}21681 \\
13410 \\
216653 \\
270998 \\
333640\end{array}$ \\
\hline
\end{tabular}


seria aumentar os limites de plantio no primeiro ano. Se fosse permitido plantar dezesseis hectares de seringueira ao invés de quinze, o aumento seria de U\$ 529,33. Se para a cana-de-açúcar fossem onze hectares, provocaria o aumento de U\$ 1088,11 .

Um pouco menos simples, seria, através do aumento da produtividade da área de cana-de-açúcar modificar a relação número de engorda de bovinos/área plantada com cana. Cono a necessidade alimentar dos animais é constante, significa que a produtividade da cana em toneladas/ha aumentaria. Entretanto, os efeitos seriam pequenos (entre Us 5,22 a U\$ 15,41, apenas no periodo do sétimo ao décimo terceiro ano chegaria a U $\$ 46,74)$.

\section{b) Situação II:}

Nesta situação, foram feitos os mesmos pressupostos da situação anterior, alterando-se apenas a disponibilidade inicial de caixa para U\$ $400.000,00$ no primeiro bimestre do primeiro ano e U\$ $250.000,00$ no primeiro bimestre do ano "estável".

Nas tabelas 4,5 e 6 , sto apresentadas, respectivemente, as atividades agropecuárias a serem desenvolvidas pela Empresa, as necessidades de mo-de-obra fixa e horas de trator, e as aplicaçóes financeiras feitas nos perfodos para essa situação.

Os resultados da tabela 4 mostran que as culturas, neste plano, como no anterior, seriam plantadas até o limite estabolecido para o primeiro ano. A 
seringueira, também nessa situaça, seria plantada já no primeiro e segundo anos em todo o seu limite de área disponivel, enquanto o plantio de cana-de-açucar, em relação ao plano anterior, altera-se na quantidade de área plantada a partir do terceiro ano e é incluido o plantio no quinto ano. A entrada da variável plantio de seringueira no quarto ano provocaria uma redução na Função objetivo em U\$ $927,64$. Para o plantio dessa cultura no quinto ano a reduça seria de U 1308,38

gabela 1, hreas de Culturas (ha) e Modulos de Criacoes a Seren Desemvoluidas nos Anos do Forizonte de Planejamento do modelo - Sitação il

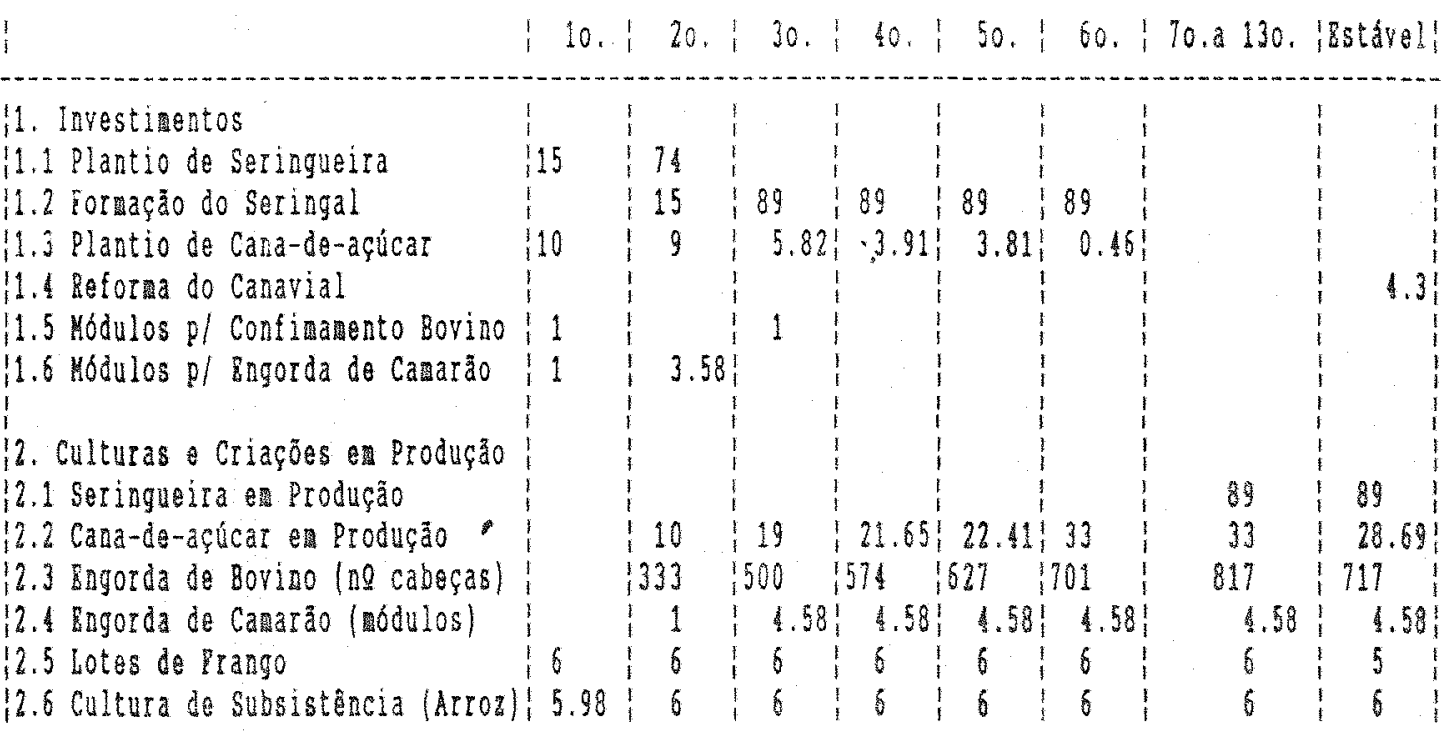

Nos investimentos da area animal, para camarão deve ser feito tambem apenas no primeixo ano. A inclusão de uma unidade desse investimento no texceiro ano 
levaria a Eunça Objetivo a reducão de U\$ 3035,11 . Para o quarto e sexto ano, a redução seria de U\$ 3666,35 , U\$ 3917,30 U $\$ 5055,56$, respectivamente. O mesmo raciocinio aplicado ao confinamento de bovinos, apresentaria as seguintes reduções como resultado:

- U\$ 2083,11 referente à introdução da variável investimento em confinamento no segundo ano

- U\$ 8416,18 para a variável do quarto ano

- U\$7205, $\$ 1$ para a variável do quinto ano

- U\$5963,12 para a variável do sexto ano

Tabela 5. Necessidade de Mão-de-Obra Fixa Comum (M.O.C.) e Mão-de-Obra Qualificada (M.O.Q.) nos Anos do Horizonte de Planejamento do modelo - Situaça II

\begin{tabular}{|c|c|c|}
\hline \multirow{2}{*}{ Ano } & \multicolumn{2}{|c|}{ No de homens } \\
\hline & M.O.C. & $M . O . Q$ \\
\hline 10. & 4.56 & 1.27 \\
\hline 20. & 19.04 & 3.22 \\
\hline 30. & 26.6 & 3.03 \\
\hline$\Delta 0$ & 26.67 & 1.7 \\
\hline 50 & 21.12 & 1.8 \\
\hline 60. & 22.6 & 1.8 \\
\hline Estável & 14.48 & 4.13 \\
\hline
\end{tabular}


Verifica-se que a necessidado de mão-de-obra fixa fol ligeiramente superior do quarto ao sexto anos e com relação a tratores, a maior utilizaçao dessas máquinas na "situação II" em alguns anos está associada ao preparo de solo para o plantio de cana-de-açúcar nesse ano.

o custo marginal associado às áreas de plantio no primeiro ano, também revela nesta situaçäo que haveria um aumento razoável na F.O. caso os limites para plantio nesse ano fossem ampliados em um hectare: U 559,09 se a seringueira passasse para dezesseis hectares ou U 1090,98 se fosse o Iimite para plantio de cana que sofresse essa variaçăo.

Quanto aos aumentos na F.O. consequentes do aumento de disponibilidade de área, iriam de U 173,77 para $\circ$ ano quatro até o máximo de U\$4057,99 para a vaxiável do ano estável (passando por U $\$ 47,39$ se o aumento fosse no ano dois ou por U\$1862,08 se esse aumento fosse no sexto ano). A mesma análise para o "solo 2 " apresentou os seguintes valores? U 99,53 ; U\$ 2453,$34 ;$ U\$ 4057,99 respectivamente para as variáveis correspondentes ao sexto, sétimo a décimo terceiro e ao ano estável.

A possibilidade de se investir em dois módulos de camara no primeiro ano, elevaria a F.o. en U⿻丷木 90,0233 . 
Tabela 6. Necessidade de Horas de Trator de Rsteira (HTE) e Trator de Pneu (HTP) e aplicaçoses financeiras por período do ano no Horizonte de Planejamento do modelo - Situação II

\begin{tabular}{|c|c|c|c|c|}
\hline Ano & Periodo & HTE & HTP & 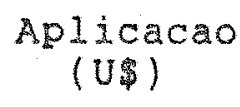 \\
\hline 10. & $\begin{array}{l}\text { Jul-Ago } \\
\text { Set-Out } \\
\text { Nov-Dez } \\
\text { Jan-Eev } \\
\text { Mar-AbI } \\
\text { Mai-Jun }\end{array}$ & $\begin{array}{l}48 \\
67.5 \\
31.67\end{array}$ & $\begin{array}{c}105.02 \\
380.76 \\
84.38 \\
7.5 \\
7.5\end{array}$ & $\begin{array}{l}398404 \\
392947 \\
373679 \\
375050 \\
374234 \\
368655\end{array}$ \\
\hline 20 & $\begin{array}{l}\text { JuI-Out } \\
\text { Nov-Pev } \\
\text { Mar-Jun }\end{array}$ & $\begin{array}{l}569.8 \\
113.5\end{array}$ & $\begin{array}{r}2369.5 \\
423.3 \\
44.5\end{array}$ & $\begin{array}{l}237990 \\
127711 \\
215664\end{array}$ \\
\hline 30 & $\begin{array}{l}\text { JuI-Out } \\
\text { Nov-Fev } \\
\text { Max-Jun }\end{array}$ & & $\begin{array}{r}2131.3 \\
51.3 \\
44.5\end{array}$ & $\begin{array}{r}355408 \\
20988 \\
169420\end{array}$ \\
\hline$\Delta 0$ & $\begin{array}{l}J u 1-O u t \\
\text { Nov-Eev } \\
M a x-J u n\end{array}$ & & $\begin{array}{c}2351.77 \\
53.8 \\
48.25\end{array}$ & $\begin{array}{r}14646 \\
191696\end{array}$ \\
\hline 50 & $\begin{array}{l}\text { JuL-Out } \\
\text { Nov-Eev } \\
\text { Mar-Jun }\end{array}$ & & $\begin{array}{c}2566.5 \\
72.3 \\
66.75\end{array}$ & $\begin{array}{c}13454 \\
2014575\end{array}$ \\
\hline 60 & $\begin{array}{l}J u L-O u t \\
\text { Mov-Fev } \\
M a r-J u h\end{array}$ & & $\begin{array}{c}2728.3 \\
88.96 \\
70.5\end{array}$ & $\begin{array}{r}13685 \\
228251\end{array}$ \\
\hline Estável & $\begin{array}{l}\text { Jul-Ago } \\
\text { Set-Out } \\
\text { Nov-Dez } \\
\text { Jan-Fev } \\
\text { Mar-Abr } \\
\text { Mai-Jun }\end{array}$ & $\begin{array}{r}14.48 \\
4.13 \\
53.8 \\
98.8\end{array}$ & $\begin{array}{c}1415035 \\
1448.88 \\
117.1\end{array}$ & $\begin{array}{r}32716 \\
12249 \\
298073 \\
352071 \\
113788\end{array}$ \\
\hline
\end{tabular}




\section{c) Situação III:}

Considerou-se nesta situação, que o dinheiro não estaria totalmente disponivel no primeiro bimestre e sim que a cada periodo uma quantia seria colocada a disposição da empresa. Assim, nos seis primeiros bimestres e nos dois primeiros do ano estavél, essa quantia é U 50 000,00 . No segundo ano, essa mesma é atribulda por quadrimestre. Essa foi a única alteraça em relaça a situações I e II apresentadas e resultou-se no plano apresentado nas tabelas 7 a 9 .

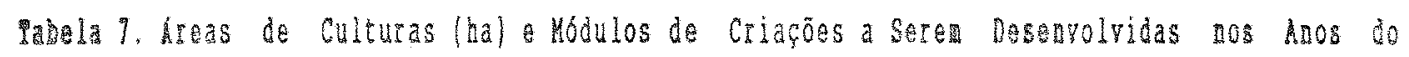
Borizonte de Planejamento do mocielo - Sitação III

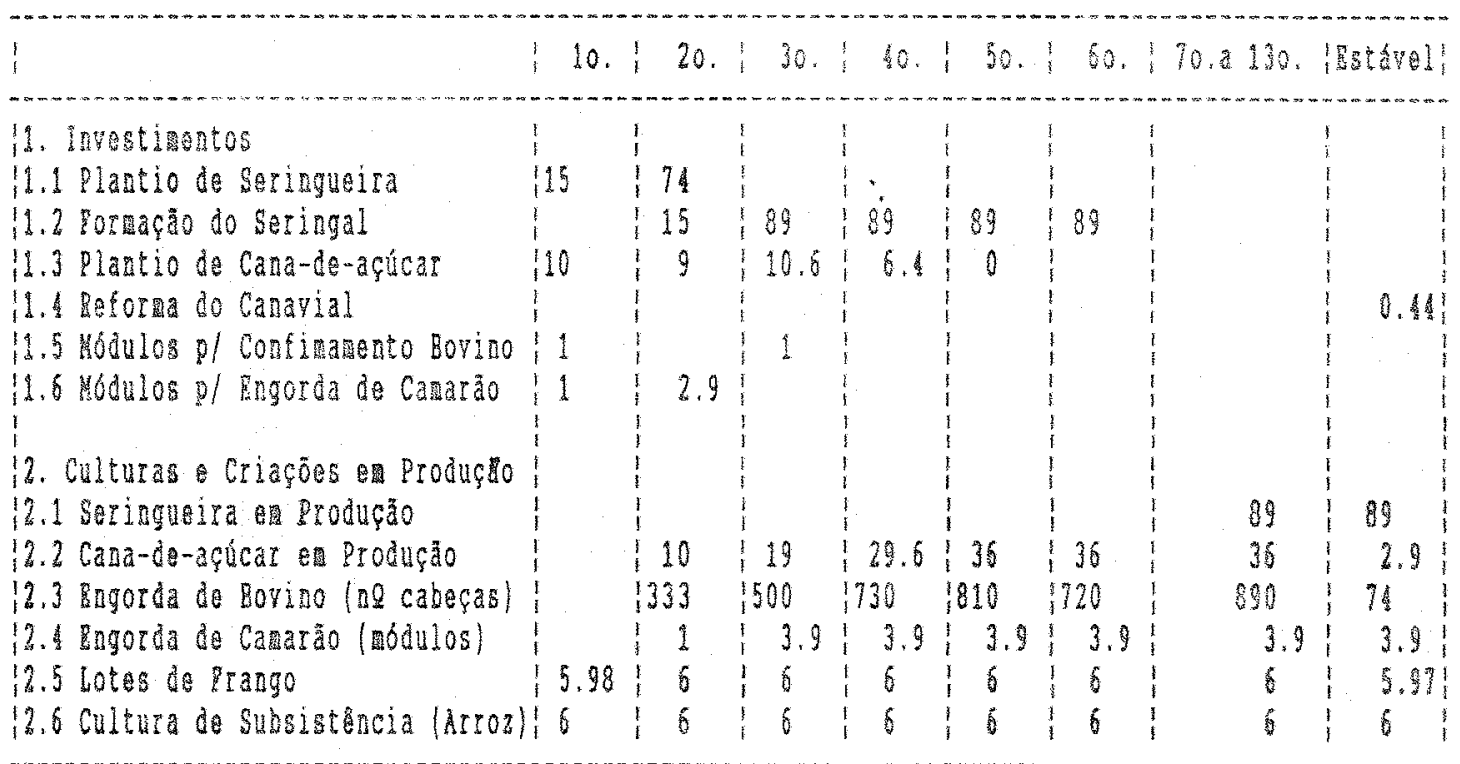

A distribuição do plantio de seringueira ao longo dos anos seria a mesma das situaçoss antoriores. As 
atividades de plantio desta cultura no terceiro e guarto ano esta fora da soluça ótima e verifica-se que a redugão que ocorreria na Funça objetivo com a incroduça de cada uma delas seria, respetivamente de U 890,37 e U 1859,64 . A cana-de-açuar seria plantada do primeiro ao quarto aro, sendo 10,6 hectares a área máxima plantada num mesmo ano (terceiro ano) e 6,4 a área minima (quarso ano).

A principal diferença deste plano em relação aos anteriores está relacionada as criacoes. No segundo ano, 330 cabeças de gado seriam engordadas em regime de confinamento e no terceiro, 500 cabeças. Bsse

mabela 3. Necessidade de Mão-de-obra Fixa Comum (M.O.C.) e Mão-de-obra Qualificada (M.O.Q.) nos Anos do Horizonte de Planejamento do modelo - Situaço II

\begin{tabular}{|c|c|c|}
\hline \multirow[b]{2}{*}{ Ano } & \multicolumn{2}{|c|}{ No de Homens } \\
\hline & $M . O . C$ & $M .0 .0$ \\
\hline 10. & 4.55 & 1.27 \\
\hline 20. & 19 & 3.2 \\
\hline 30. & 26.7 & 3.3 \\
\hline 40 & 29.9 & 2.2 \\
\hline 50. & $24 \cdot 3$ & 2.12 \\
\hline 60. & 22.6 & 1.9 \\
\hline Estável & 10.2 & 0.43 \\
\hline
\end{tabular}


número aumentaria chegando a 890 (no periodo do setimo ao décimo terceiro ano). Entretanto, pela pequena disponibilidade de caixa na época de compra dos bois, no ano estável cairia para 74 cabeças (e a área com cana seria reduzida drasticamente). O investimento em confinamento nå entrou na solução otima nos outros anos. As reduçōes provocadas na Função objetivo com a entrada dessas variáveis seriam, U 2709,07 para a atividade de investimento no Segundo ano, U\$ 7838,26 para o quarto ano $\theta \$ 5963,12$ para a úlima atividade de investimento em confinamento (sexto ano).

o investimento em camara atingiu 3,9 módulos no segundo ano. Se no quarto ano esse número fosse expandido para um total de 4,9 módulos, na Eunção objetivo se observaria uma redução de U\$ 3222,28 . Se essa expansão fosse feita mais tarde, a redução seria maior (U\$ 4025,42 para investimento no quinto ano e U⿺辶千 5963,12 no sexto).

A utilizą̧̃o de mão-de-obra e tratores (tabelas 8 e 9) é agora maior no quarto e quinto ano a menor gue nos resultados anteriores para o ano "estavel".

O custo marginal associado às áreas do plantio no primeiro ano, säo bastante proximos dos rosultados obtidos anteriormente: podendo-se plantar un hectare a mais os aumentos na $F \cdot 0$. serian: U 616,35 para a seringueira ou U 990,77 se fosse o limite para plantio de cana gue sofresse essa variaça. 
Tabela 9. Necessidade de Horas de Trator de Esteira (HTR) e Trator de Pneu (HTP) e aplicaçes financeiras por periodo do ano no Horizonte de planejamento do modelo - Situação III

\begin{tabular}{|c|c|c|c|c|}
\hline Ano & Periodo & $\mathrm{HTE}$ & $\mathrm{HIP}$ & $\begin{array}{c}\text { Aplicacao } \\
(U)\end{array}$ \\
\hline 10. & $\begin{array}{l}\text { Ju1-Ago } \\
\text { Set-Out } \\
\text { Nov-Dez } \\
\text { Jan-Fev } \\
\text { Mar-Abr } \\
\text { Mai-Jun }\end{array}$ & $\begin{array}{l}48 \\
67.5 \\
31.67\end{array}$ & $\begin{array}{l}105 \\
380 \\
84.4 \\
7.5 \\
7.5\end{array}$ & $\begin{array}{r}48404 \\
89437 \\
117123 \\
165919 \\
213003 \\
255801\end{array}$ \\
\hline 20 & $\begin{array}{l}\text { Jul-Out } \\
\text { Nov-Fev } \\
\text { Mar-Jun }\end{array}$ & $\begin{array}{r}569.8 \\
92.3\end{array}$ & $\begin{array}{r}2369.5 \\
423.3 \\
44.5\end{array}$ & $\begin{array}{l}174148 \\
120378 \\
262118\end{array}$ \\
\hline 30 & $\begin{array}{l}\text { Jul-Out } \\
\text { Nov-Fev } \\
\text { Mar-Jun }\end{array}$ & & $\begin{array}{r}2286 \\
54.2 \\
44.5\end{array}$ & $\begin{array}{r}84952 \\
71381 \\
220648\end{array}$ \\
\hline 40 & $\begin{array}{l}\text { Jul-Out } \\
\text { Nov-Fev } \\
\text { Max-Jun }\end{array}$ & & $\begin{array}{r}3032 \\
55.4 \\
48.25\end{array}$ & $\begin{array}{r}65755 \\
235002\end{array}$ \\
\hline 50 & $\begin{array}{l}\text { Jul-Out } \\
\text { Nov-Fev } \\
\text { Max-Jun }\end{array}$ & & $\begin{array}{l}3118 \\
69.9 \\
66.7\end{array}$ & $\begin{array}{r}1404 \\
262142\end{array}$ \\
\hline 60 & $\begin{array}{l}\text { Jul-Out } \\
\text { Nov-Fev } \\
\text { Max-Jun }\end{array}$ & & $\begin{array}{r}2728 \\
88.7 \\
70.5\end{array}$ & $\begin{array}{r}66805 \\
54165 \\
289844\end{array}$ \\
\hline Bstsval & $\begin{array}{l}\text { Jul-Ago } \\
\text { Sot-Oui } \\
\text { Mov-Dez } \\
\text { Jan-Fev } \\
\text { Mar-Abr } \\
\text { Mai-Jun }\end{array}$ & $\begin{array}{r}5.5 \\
10.1\end{array}$ & $\begin{array}{l}150.5 \\
151.2 \\
114.7 \\
111.2\end{array}$ & $\begin{array}{r}4488 \\
59947 \\
125276 \\
179079 \\
241359\end{array}$ \\
\hline
\end{tabular}


Aumentos na disponibilidade de área, iriam de un valor máximo no quarto ano (U\$ 2835,91 ) até o mínimo (de U\$ 1107,98 no período do sétimo ao décimo terceiro ano. A mesma análise para 0 "solo 2" apresentou os seguintes valores: U\$ 419,$84 ;$ U 387,30 e U\$ 2324,17 respectivamente para as restrições correspondentes ao quinto, sexto, sétimo a décimo terceiro ano.

Outro resultado a ser observado, também através do "preço sombra", é que permitindo-se o aumento do investimento em camară em um módulo, haveria um crescimento da P.O. de U 803,74 .

\section{d) Situação IV:}

A mesma idéia aplicada na situação anterior quanto à disponibilidade de caixa é encontrada nesta, com a diferença apenas nos valores disponfveis por bimestre no "ano estável" (apenas U⿳亠丷厂巾 10 000,00 em cada um dos três primeiros bimestres). Nas restriçōes de plantio, há uma alteração em relação às três situaçōes anteriores: apenas no segundo ano é permitido plantar até o limite de área disponivel, ou seja, em todos os outros anos (do primeiro ao sexto), o plantio de seringueira esta limitado em quinze hectares e o plantio de cana em dez. Provavelmente, a principal diferença desta situação em relação as anteriores se encontra no fato de que nesta a criação de camarão esteja concorrendo en ärea com a cana-de-açúcar para engorda de bovinos e essa área é a área 
total mecanizável (trinta e oito hectares).

os resultados, apresentados nas tabelas 9 a 11, foram bastante semelhantes aos anteriores guanto as atividades de plantio: seringueira tem valores identicos aos anteriores e a cana-de-açúcar foj plantada do primeiro ao sexto ano (mas nunca em áreas täo pequenas como antes, sempre nove ou dez hectares). Para cada hectare de seringueira que fosse plantado no terceiro ano, a reduça na Função objetivo seria de U\$ 914,53 ; feito no quarto ano esse investimento reduziria a Função objetivo em U\$ 1903,16 - no quinto a redução seria pequena (apenas U 24,81 ). Importante notar que o investimento em camarão nao entrou na solução ótima em nenhum ano e se entrasse, provocaria uma redução de U\$ 3184,64 (para este investimento feito no segundo ano), U\$ 5529,39, U\$ 6858,52, U\$ 7748,24 ou U\$ 915,93 de acordo com o ano em que fosse feito (do terceiro ao sexto).

Assim, para uma situação em que seja feito investimento em bovino no terceiro e exto ano, melhor plantar a área toda mecanizável con cana para alimentar esses animais, mesmo que haja pouco dinheiro disponfvel para - ano ostável (onde a engorda de bois seria de apenas trinta - quatro cabeças e com a consequente diminuição da área de cana-de-açúcar). 
Pagela 10. Rreas de culturas (tha) a Modulos de criações a Seren Desenvolvidas nos hos do Horizonte de Planejamento do modelo - Sitação IV

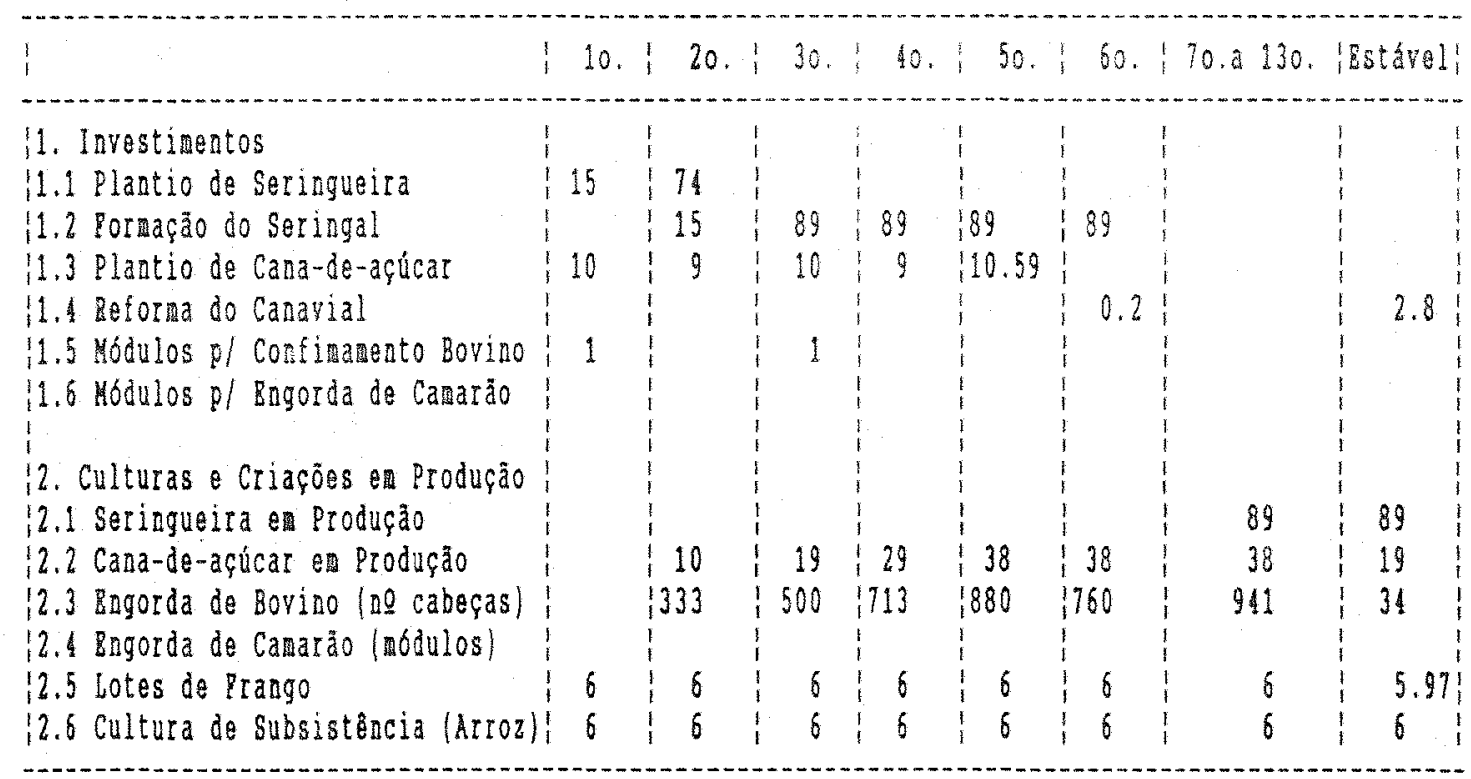

Os custos marginais associados às áreas de plantio no primeiro ano, são bastante próximos aos resultados obtidos anteriormente: podendo-se plantar un hectare a mais os aumentos na F.O. seriam: U: 538,70 para a seringueira ou U 1050,58 se fosse o limite para plantio de cana que sofresse essa variaça. No caso de se liberar um hectare a mais para o plantio de cana-de-acúcar no torceiro ano, U\$ 438,20 seriam acrescentados aे $\vec{F}$.

Com relação aos aumentos na F.o. resultantes do aumento de disponibilidade de area, seriam de U 2888,52 para o ano quatro U\$ 1288,10 para a restrição do quinto ano, U\$ 1859 e U\$1205,99, respectivamente para esse aumento no sexto ano ou no perído do setimo ao décimo 
Tabela 11. Necessidade de Mão-de-Obra Fixa Comum (M.O.C.) e Mão-de-Obra Qualificada (M.O.Q.) nos Anos do Horizonte de Planejamento do modelo - Situacão IV

\begin{tabular}{|c|c|c|}
\hline \multirow{2}{*}{ Ano } & \multicolumn{2}{|c|}{ No de Homens } \\
\hline & M.O.C. & M.O.Q. \\
\hline 10. & 4.56 & 1.27 \\
\hline 20 & 18.56 & 3.22 \\
\hline 30. & 24.69 & 3.22 \\
\hline 40. & 27.8 & 2.28 \\
\hline 50 & 23.9 & 2.3 \\
\hline 60. & 21.52 & 1.99 \\
\hline Estável & 6.3 & 0.3 \\
\hline
\end{tabular}

terceiro. Para o "solo 2 " esta"situaça IV" apresentou os seguintes valores: U\$453,44; U 378,37 U U 2374,35 respectivamente para as restrições referentes ao quinto, sexto e setimo a détimo terceiro, nessa sequencia.

Para as restrições de nutrição de bovinos com cana-de-açúcar, os incrementos na F.O., de acordo com os "preços sombra" são bem proximos dos resultados da situaça anterior (iqualmente pequenos). Quanto a criaca do frangos, - aumento de uma unidade na capacidade instalada aumentaria a F.O. (como nos resultados anteriores), mas deve ser lembrado que isso, na realidade, implicaria num investimento 
Tabela 12. Necessidade de Horas de Trator de Esteira (HTE) e Trator de Pneu (HTP) e aplicações financeiras por perído do ano no do Horizonte de Planejamento do modelo - Situação IV

\begin{tabular}{|c|c|c|c|c|}
\hline Ano & Período & $\mathrm{HTE}$ & HTP & $\begin{array}{c}\text { Aplicação } \\
\text { (U\$) }\end{array}$ \\
\hline 10. & $\begin{array}{l}\text { Jul-Ago } \\
\text { Set-Out } \\
\text { Nov-Dez } \\
\text { Jan-Fev } \\
\text { Mar-Abr } \\
\text { Mai-Jun }\end{array}$ & $\begin{array}{l}48 \\
67\end{array}$ & $\begin{array}{c}105.02 \\
380.8 \\
84.4 \\
7.5 \\
7.5\end{array}$ & $\begin{array}{r}48627 \\
89665 \\
126854 \\
177863 \\
229341 \\
273916\end{array}$ \\
\hline 20 & $\begin{array}{l}\text { Jul-Out } \\
\text { Nov-Fev } \\
\text { Mar-Jun }\end{array}$ & 569.8 & $\begin{array}{c}2369.55 \\
423.3 \\
44.5\end{array}$ & $\begin{array}{l}200781 \\
181528 \\
341776\end{array}$ \\
\hline 30 & $\begin{array}{l}\text { Jul-Out } \\
\text { Nov-Fev } \\
\text { Mar-Jun }\end{array}$ & & $\begin{array}{r}2286 \\
53.9 \\
44.5\end{array}$ & $\begin{array}{l}185699 \\
174683 \\
326690\end{array}$ \\
\hline 40 & $\begin{array}{l}\text { Jul-Out } \\
\text { Nov-Fev } \\
\text { Mar-Jun }\end{array}$ & & $\begin{array}{c}3044.7 \\
57 \\
.4825\end{array}$ & $\begin{array}{r}108334 \\
94950 \\
325977\end{array}$ \\
\hline 50 & $\begin{array}{l}\text { JuI-Out } \\
\text { Nov-Fev } \\
\text { Mar-Jun }\end{array}$ & & $\begin{array}{r}3398.2 \\
69.9 \\
66.75\end{array}$ & $\begin{array}{l}66083 \\
52772 \\
34156\end{array}$ \\
\hline 60 & $\begin{array}{l}\text { Jul-Out } \\
\text { Nov-Fév } \\
\text { Mar-Jun }\end{array}$ & & $\begin{array}{r}2933.8 \\
88.7 \\
70.5\end{array}$ & $\begin{array}{l}116562 \\
105153 \\
355970\end{array}$ \\
\hline Estável & $\begin{array}{l}\text { Jul-Ago } \\
\text { Set-Out } \\
\text { Nov-Dez } \\
\text { Jan-Fev } \\
\text { Mar-Abr } \\
\text { Mai-Jun }\end{array}$ & $\begin{array}{l}2.5 \\
4.6\end{array}$ & $\begin{array}{l}72.4 \\
71.05 \\
11.56 \\
111.25\end{array}$ & $\begin{array}{r}7067 \\
32278 \\
84124 \\
138056 \\
200734\end{array}$ \\
\hline
\end{tabular}

(não previsto no modelo). Outra forma de interpretação 
seria dizer que nas mesmas instalaçōes jáa existentes, o proprietário passaria a criar o dobro de frangos lo que, evidentemente, na prática é inviável).

o objetivo dessas análises de sensibilidade não foi escolher o melhor plano, mas sim apresentá-los para que possam orientar a tomada de decisōes em situações diferentes que poderiam ser enfrentadas na prática. As quantias iniciais colocadas a disposição da empresa influenciam nos resultados obtidos para a F.o. não só através das atividades agropecuárias, mas também através das variáveis de aplicação de recursos no sistema financeiro. Contudo, observou-se que o major valor da F.o. fol obtido na "situação II" (U\$ 1 148 068,00) seguida de perto pelas outras : "situação III" (U\$ 1 108 985,00), "situação IV" (U\$1 091866,07 ) e "situação I" (U\$ 1041 $819,83)$

Através dos planós obtidos, verifica-se que a disponibilidade de área é um fator efetivamente restritivo: aumentos de area disponiveis tanto do solo nå mecanizável quanto do mecanizável, excluindo-se a área de várzea, aumentariam os valores da Funçäo objetivo. Outro fator limitante importante observado foi o limite de plantio estabelecido para as culturas no primeiro ano e limite de investimento em instalaçöes para camarão no mesmo ano. Esses limites, estabelecidos arbitrariamente, emboxa justificáveis, merecem ser repensados. 


\subsection{O Pluxo de Caixa}

Com o objetivo de se discutir a estrutura

do Fluxo de Caixa e o Plano de Contas sugeridos para o controle contábil da empresa, serão apresentadas algumas estruturas de FC existentes. Essas estruturas são resultados dos diversos objetivos dos autores a serem mencionados.

Em geral, os autores apresentam em comum a divisão horizontal do $F C$ em Entradas, Saidas e Caixa Final, embora a divisão vertical também ocorra, como no sumário do EC apresentado por TUNG (1990), p. 247.

Os itens de entrada e saía são apresentados com os respectivos valores monetários para o perído considerado. A sequência desses itens "não obedece a normas rigidas. Dependendo da natureza e da importancia de seus itens de receita e desembolso, cada empresa estabelece uma sequencia que the seja mais fácil para determinar suas disponibilidades ou necessidades de caixa. (TUNG, 1990)". Feita essa observação, o mesmo autor apresenta uma ostrutura para o $\mathrm{EC}$ de uma empresa agropecuária em que, além das divisöes tradicionais de entradas e saldas e do saldo inicial de caixa, acrescenta uma outra: Ajustes. Esses ajustes consistem nas novas aplicaçöes, novos empréstimos e - saldo final. As entradas estäo divididas em Receitas Operacionais, Receitas de Capital e Outras Receitas. SaIdas dividem-se em Despesas variaveis e Semi-variaveis, Despesas Fixas, Aquisisôs de Bens de Capital e Outros Desembolsos. 
Quando o objetivo é análise de projetos de investimento, OFC deve ser apresentado de forma a permitir a separação entre desembolsos para investimentos e para manutenção. E o caso da estrutura apresentada por Noronha (1981), p. 128 .

Com finalidade gerencial, há a estrutura adotada por SANTOS (1991) a partir da proposta de LEE et alli (1980). Nessa estrutura há itens de transação de caixa e transações de crédito. Os primeiros consistem em alteraçōes feitas ao caixa inicial para se obter o caixa final. Esses acréscimos são: "deficit" ou "superavit" do periodo (entradas - saidas), pagamento de dividas (principal + correção monetária) e as parcelas de novas dividas contraidas. Em transações de créditos o objetivo é chegar às obrigações totais finais, acrescentando-se às iniciais as parcelas de novas dividas contraidas e subtraindo-se o pagamento de dividas efetuado iprincipal + correça monetária).

O FC a ser proposto neste trabalho deveria possibilitar a comparaça com o Fluxo de caixa gerado no planejamento, portanto optou-se por um demonstrativo bimestral, multicolunar, onde há uma coluna destinada a cada atividade agropecuária em produção e colunas para as fases de investimento. Por exemplo: seringueira apresenta duas colunas, uma para a fase produtiva (onde serão incluidas entradas e saldas referentes a cultura a partir do setimo ano) e outra para o periodo de investimento lpara as saldas 
do primeiro ao sexto ano e a pequena entrada de caixa que deverá ocorrer no sexto ano). Essa estrutura resultou no FC apresentado na Tabela 13.

Além das colunas de produçao $\theta$ investimento, há ainda uma coluna que não representa nenhuma atividade agropecuária especifica: Empresa. Nesta coluna serão apresentados os totais de entradas e saldas de caixa da empresa toda, ou seja: a soma das entradas e das saidas de cada atividade agropecuária e ainda os itens que não poden ser atribuidos a nenhum outro centro de custos por estarem relacionados à empresa como um todo.

Portanto, será apenas nesta coluna que será preenchido o valor do "Deficit" ou "Superavit". Este valor será calculado de acordo com a fórmula:

\section{DEFICIT OU SUPERAVIT \\ $=$ ENTRADAS - SAIDAS}

Em seguida ao "déficit ou superavit" há um resumo do que ocorreu no cajxa no periodo (Transaçóes de caixa), ondé o caixa final é apresentado. O cálculo do valor do caixa final é através dos valores apresentados nos outros sub-itens deste resumo, de acordo com a formula:

$$
C P_{t}=C I_{t}+(D / S)_{t}-P E_{t}+N D C_{t}-A P_{t}+R A P_{t}-P I_{t}
$$


Pabela 13. Demonstrativo da Pluro de Caira.

Birestre:

PHOR BRA EM DOLAR

ITPES

ATIVDADR EM PRODUÇA

INISTIMRTOS losos tpongen:

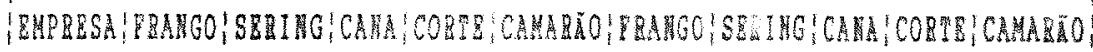

11. IETMEADAS

11.1. Vendas de Produtos Agropecuários

11.2 Prestaçäo de serviços p/ terceiros

11.3 Receitas de Capital

1.3.1) Veada de máguinas, vefculos, equipamentos e inglementos

11.5 Outras entradas de caiza

12. SRIDAS

12.1 Compras de Háquinas, Velculos

I Equipamentos e Iaplementos

12.2 Despesas coa novas Construções,

1. Instalaçojes a Melboramentos

12.3 Não-de-Obra Permanente

12.4 Combustiveis e Lubrificantes

12.5 Pertilizantes, Corretivos, Defensi-! Sementes e Mudas

12.6 Hateriais de Consumo

12.7 Compra de hninais p/Criaçäo/engorda!

12.8 Minentaçẵo Animal

12.9 Hedicamentos a Vacinas

2.10 Reparos e Manutenção de Máquinas, - Veiculos, Inplementos equipamentos!

12.11 Comoras de Máquinas, velculos

I Bquipanentos e Implementos.

12.12 Sorviços de Farcoiros

12.13 gazas, Impostos, geguros a Licenças!

12.14 Muguéis e Arrondanentos

12.15 Paganento do inposto de anda

12.16 Despesas con Vendas

12.17 Despesas ddinistrativas

12.18 Despesas Pinanceiras

12.19 Ontras Saloias

13. DRPICI $(-)$ OO SUPBRAMI $(t)(1-2)$

1. THAMACOBS o8 CAIX

11.1 Caira Inicial

1 1.2 Deficit ou Superavit

11.3 Pagamento de Baprestimo

14.1 Movas Dividas Contraldas

14.5 Aplicaçoes Tinanceiras (Mercado de (Capitais)

11.6 Retiradas de Aplic. Minancsiras

14.7 Perdas por Inflação

11.8 Caja Pinal

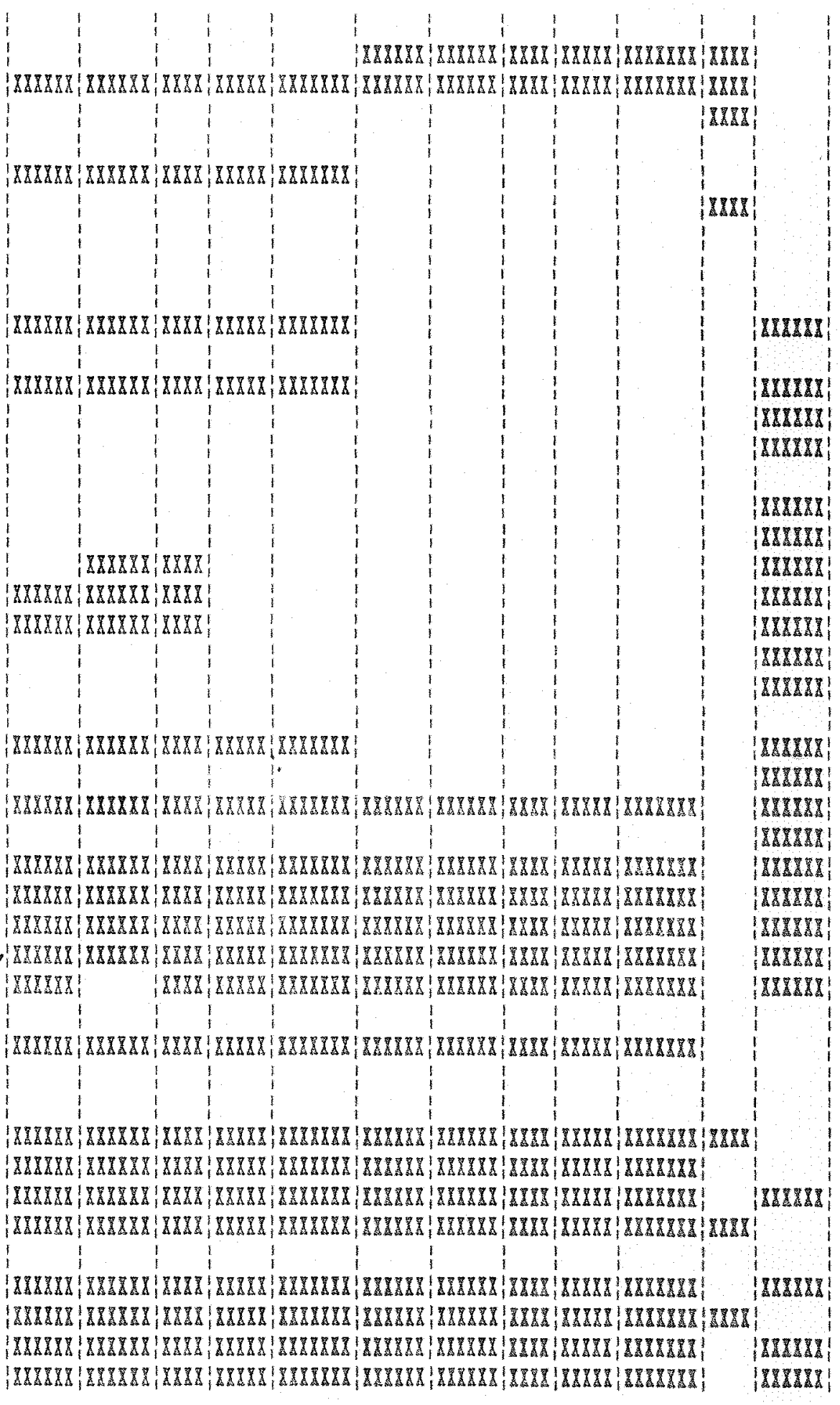


onde:

$$
\begin{aligned}
C F_{t}= & \text { Caixa Final no periodo " } t " \\
C I_{t}= & \text { Caixa Inicial no periodo "t-1" } \\
D / S_{t}= & \text { "Déficit/Superavit" no periodo " } t " \\
\mathrm{PE}_{t}= & \text { Pagamentos de Empréstimos no periodo "t" } \\
& \text { (inclui principais + correções monetárias } \\
& \text { do mês " } t " \text { ) } \\
\mathrm{NDC}_{t}= & \text { Novas Dividas Contraidas no perído "t" } \\
\mathrm{AF}_{t}= & \text { Aplicações Financeiras realizadas no periodo } \\
& \text { "t" } \\
\mathrm{RAF}_{t}= & \text { Retiradas de Aplicações Financeiras no } \\
& \text { periodo "t" } \\
\mathrm{PI}_{t}= & \text { Perdas por Inflação no periodo "t" }
\end{aligned}
$$

inicial de cada período conservaria seu valor real ao longo do bimestre. Sabe-se que isso não ocorre na realidade, portanto deve-se calcular as perdas por inflaça (PI) sobre - caixa inicial do perfodo, considerando-se a mudança no deflator, que para a empresa analisada é a taxa de câmbio entre o inicio e o final do bimestre:

$$
P I_{t}=\left[C F_{t-1} \text { (em Cruzeiros)/Pt-1 }\right]-C P_{t-1} \text { (em Cruzeiros) } / P_{t}
$$
onde:

$$
p_{t}=\text { taxa de câmbio no período " } t \text { " }
$$

Supondo-se que no primeiro bimestre do ano 199x a "Empresa Próspera" terminasse com um Caixa Final de 
Cr 20.000,00 e que as taxas de cambio tossem: Crip 100,00 / U\$1,00 no inicio do 22 bimestre e Cr\$120,00/U\$1,00 no Iinal do bimestre, o valor da perda por inflaça no segundo bimestre seria:

$$
\begin{aligned}
P I_{2}= & C r 20000,00 /(\mathrm{Cr} \$ 100,00 / \mathrm{U} \$ 1,00)- \\
& C r \$ 20000,00 /(\mathrm{Cr} \$ 120,00 / \mathrm{U} \$ 1,00) \\
P I_{2}= & U \$ 33,33
\end{aligned}
$$

Assim, no F.C. do periodo "t", o C.I. seria Cr $20.000,00$ e as perdas por inflacäo 33,33 .

$$
\text { Os itens de Transacões de caixa }
$$

relacionam-se com a empresa como um todo e portanto as únicas colunas a serem preenchidas por estes itens sa: Empresa e Usos e Fontes. Através destas últimas colunas 6 que se verifica a identidade que é a base da estrutura do $\mathrm{FC}$ (total de Usos Recursos = total de Fontes de Recursos).

Entre o FC real e o planejado, deverá ocorrer alguns desvios, alguns dos quais serão rapidamente aprosontados. A prestaga de serviços a terceicos nao esta cntro os objotivos' atuais aos proprietarios, mas con a implantacia do plano, devera ocorrer ociosidade de máninas - en deserninadas bpocas, tambern de não-de-obra. Isto devara lavar a uma reavaliaca do objativo inicial optando-se por incluir prostacao de servicos a tercoiros. Assim, se nas forem feitas alsarages to modelo de panojamento a fin de se incluir asea possibilidado, ocorrera un dervio on rolaço ao planetado. 
Outros desvios entre planejado e realizado poderão ocorrer em função da possibilidade de estocagem de produtos e do pagamento e recebimento de contas a prazo. Essas possibilidades não estão sendo consideradas no modelo de planejamento e portanto não serão incluldas no plano de Contas a ser proposto. As Contas incluidas no plano representam apenas possiveis entradas e saldas de caixa. Futuramente o plano deverá vir a ser expandido tornando-se necessárias alterações no planejamento. Para o controle apenas do $\mathrm{BC}$ suficiente 0 Elenco de Contas apresentado a seguir.

\subsection{O Plano de Contas}

Para ser um instrumento de controle de caixa, o plano de Contas foi desenvolvido com a mesma estrutura que o FC, ou seja, dividido entre Fontes e Usos do Caixa. A codificação do Plano obedeceu ao critério utilizado por SANTOS (1991), com algumas modificaçóes: do primeiro ao quarto grau a codiflcação é decimal (a cada desdobramento adicionam-se algarismos separados por um ponto). A partir do quinto grau, $e ́$ usada a extensão de três dígitos. Esta extensão identifica elementos mais especificos (001 a 009 ) ou atividade de produção agrícola ou animal (100 a 997), ou algumas Fontes e Usos da Empresa como um todo (998) ou um Centro de Resultados Indiretos (999).

Em centro de entradas e saldas indiretos 
serão registradas entradas e saldas que não puderam $s \in \mathbb{E}$ diretamente alocadas a nenhuma atividade especifica, mas deverão vir a ser através de algum criterio de rateio, por exemplo o consumo de combustiveis dos tratores no bimestre que pode ser rateado entre as atividades através do numero de horas trabalhadas com trator em cada atividade - critério esse utilizado no planejamento.

Fontes e Usos da Empresa "como um todo" não serão rateados entre as atividades. Essa extensão fica reservada para alguns casos em que será possivel conhecer o valor a ser atribuido para cada atividade especifica e o valor que corresponde a empresa em geral. Por exemplo: materiais de consumo. Alguns materiais sao utilizados para atividades especificas, outros ficam a disposiça para gastos gerais da empresa (manutenção de jardim, pomares, etc...). Desta forma, optou-se por uma extensão para a empresa em geral que não terá, no $F \dot{C}$, uma coluna exclusiva. No FC O que aparece na coluna Empresa é a soma dos valores de entradas e das saidas de toda a empresa (tanto os valores que possan ter sido atribuldos a atividades especificas quanto os que năo possam ser desdobrados). 
Tabela 1. Sub Elenco de Contas para Empresa Rural:

$$
\text { Fazenda "Prospera". }
$$

\begin{tabular}{|c|c|c|c|}
\hline Grau & $\begin{array}{l}\text { Código a } \\
\text { destacar }\end{array}$ & Extensão & Nome da Conta \\
\hline $\begin{array}{l}5 \\
6 \\
7\end{array}$ & $\begin{array}{l}00.00 .00 \\
00.00 .00 \\
00.00 .00\end{array}$ & $\begin{array}{l}-100 \\
-\quad 110 \\
-\quad 111\end{array}$ & $\begin{array}{l}\text { Culturas Anuais } \\
\text { Arroz em gräo } \\
\text { Arroz em Crescimento }\end{array}$ \\
\hline $\begin{array}{l}5 \\
6 \\
7 \\
7\end{array}$ & $\begin{array}{l}00.00 .00 \\
00.00 .00 \\
00.00 .00 \\
00.00 .00\end{array}$ & $\begin{array}{l}-200 \\
-210 \\
-211 \\
-\quad 212\end{array}$ & $\begin{array}{l}\text { Culturas perenes } \\
\text { Seringueira } \\
\text { Seringueira em produção } \\
\text { Seringueira em formação }\end{array}$ \\
\hline $\begin{array}{l}5 \\
6 \\
7 \\
7\end{array}$ & $\begin{array}{l}00.00 .00 \\
00.00 .00 \\
00.00 .00 \\
00.00 .00\end{array}$ & $\begin{array}{l}-300 \\
-\quad 310 \\
-\quad 311 \\
-\quad 312\end{array}$ & $\begin{array}{l}\text { Animais e produtos animais } \\
\text { Pecuaria de corte } \\
\text { Confinamento de Bovinos } \\
\text { Investimento em Pecuaria de } \\
\text { Corte }\end{array}$ \\
\hline $\begin{array}{l}6 \\
7\end{array}$ & $\begin{array}{l}00.00 .00 \\
00.00 .00\end{array}$ & $\begin{array}{l}-320 \\
-\quad 321\end{array}$ & $\begin{array}{l}\text { Avicultura } \\
\text { Frango de Corte }\end{array}$ \\
\hline $\begin{array}{l}6 \\
7 \\
7\end{array}$ & $\begin{array}{l}00.00 .00 \\
00.00 .00 \\
00.00 .00\end{array}$ & $\begin{array}{l}-\quad 330 \\
-\quad 331 \\
-\quad 332\end{array}$ & $\begin{array}{l}\text { Camarão } \\
\text { Camarão em produça } \\
\text { Investimento em camarão }\end{array}$ \\
\hline 5 & $\begin{array}{l}00.00 .00 \\
00.00 .00\end{array}$ & $\begin{array}{r}-400 \\
-\quad 997\end{array}$ & $\begin{array}{l}\text { Outras atividades } \\
\text { agropecuária }\end{array}$ \\
\hline 7 & 00.00 .00 & -998 & $\begin{array}{l}\text { Centro de entradas a saldas } \\
\text { da empresa como um todo }\end{array}$ \\
\hline 7 & 00.00 .00 & -999 & $\begin{array}{l}\text { Centro do entradas e saldas } \\
\text { indiretos }\end{array}$ \\
\hline
\end{tabular}


TaDola 15. BLENCO DE COHMAS PARA CONMABILIDADE REMME CAIXA

EMPRBSA RURAL: "Eazenda Próspera"

\begin{tabular}{|c|c|c|}
\hline GRAU & CODIGO & MOME DA CONTA \\
\hline 1 & 1. & RONTES DE RECURSOS \\
\hline 2 & 11. & ENTRADAS DE CAISA \\
\hline 3 & 11.01 & Vendas de Produtos Agropecuários \\
\hline$\frac{4}{2}$ & 11.01 .00 & Vendas de Produtos Agropecuários \\
\hline 6 & $11.01 .00-110$ & Venda de Arroz \\
\hline 6 & $11.01 .00-210$ & Venda de Latex \\
\hline 6 & $11.01 .00-220$ & Venda de Cana-de-Açúcar \\
\hline 6 & $11.01 .00-310$ & Venda de Bois \\
\hline 6 & $11.01 .00-320$ & Venda de Frangos \\
\hline 6 & $11.01 .00-330$ & Venda de Camaräo \\
\hline$\cdot$ & $\cdot$ & $\because$ \\
\hline 3 & 11.02 & Prestação de Servicos p/terceiros \\
\hline 4 & 1.1 .02 .00 & $\begin{array}{l}\text { Prestaço de serviços } \\
\text { p/terceiros }\end{array}$ \\
\hline 3 & 11.03 & Receitas de Capital \\
\hline 4 & 11.03 .00 & Receitas de Capital \\
\hline 4 & 12.03 .01 & $\begin{array}{l}\text { Venda de máquinas, veiculos, } \\
\text { equipamentos a implementos }\end{array}$ \\
\hline 4 & $11.03 \cdot 02$ & Venda de terra \\
\hline 3 & 11.04 & Outras gntradas de Caira \\
\hline
\end{tabular}


Tabe1a 15. ELENCO DE CONTAS PARA CONTABILIDADE RECISE CAIXA

BMPRESA RURAL: "Eazenda Próspera"

GRAU CODIGO

4

2

3

4

4

4

3

4

4

3

4

4

4

1

2

3
11.04 .00

12 .

12.01

12.01 .10

12.01 .11

12.01 .12

12.02

12.02 .10

12.02 .20

12.03

12.03 .01

12.03 .02

12.03 .03

2

21.

21.01
NOME DA CONTA

Outras Entradas de Caixa

OUTRAS FONTES

Caixa Inicial

Bancos Conta Corrente

Banco c/ Movimento "A"

Banco c/ Movimento "B"

Novas Dlvidas Contraidas

Empréstimos

Einanciamertos

Retiradas de Aplicaçes

Financeiras

Poupança

Funcio de...

Open Market

USOS DE RECURSOS

SAIDAS DE CAIXA

Compras de Máquinas, Veiculos,

Equipamentos e Implementos 
Tabela 15. ELENCO DE CONTAS PARA CONTABILIDADE REGLMB CAIXA

BMPRESA RURAL: "Fazenda Próspera"

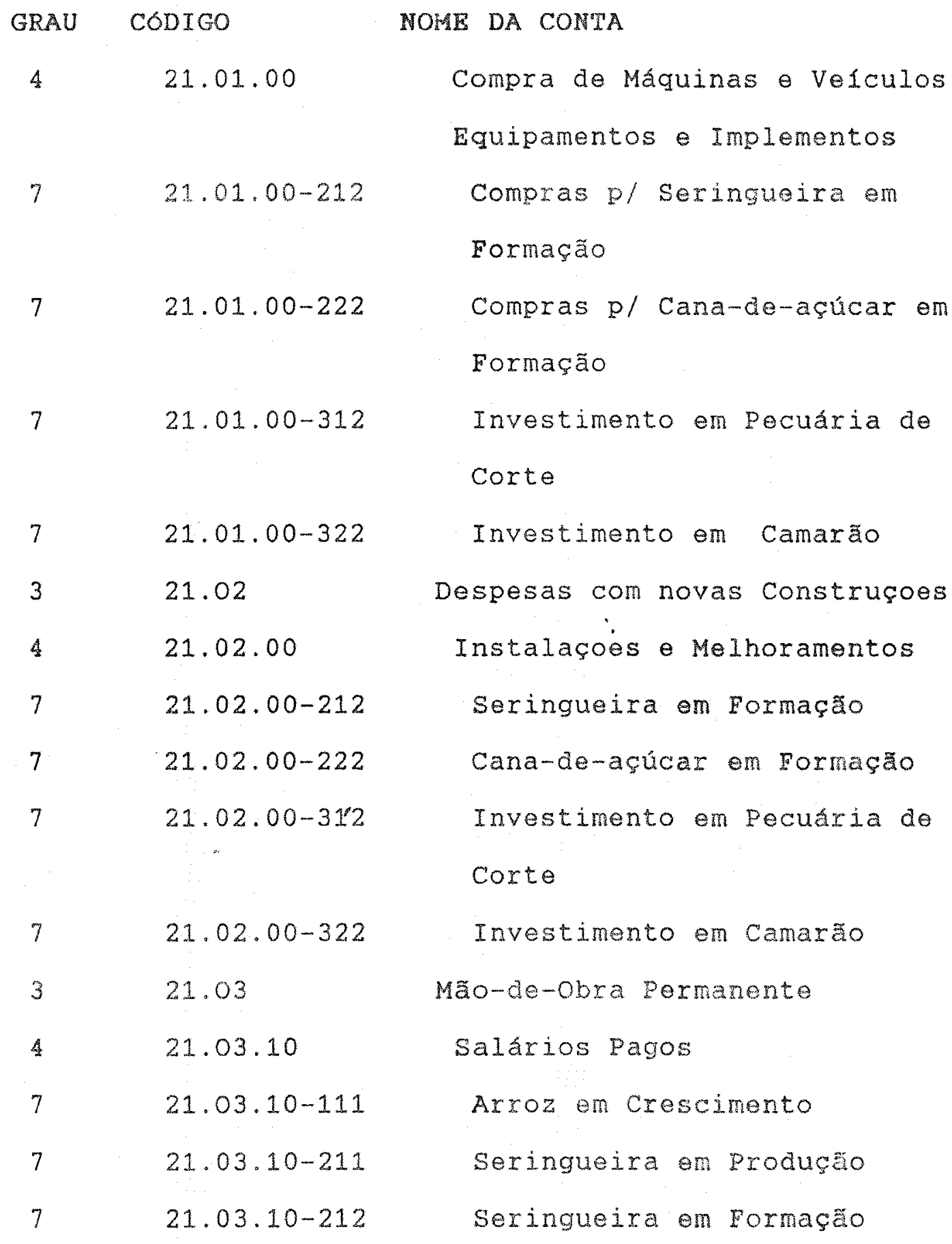


Tabola 15. ELENCO DR CONRAS PARA CONTABILIDADE REGIMB CAIXA

BMPRESA RURAL: "Fazenda próspera"

GRAU CODIGO

7

7

7

7

7

7

7

4

4

3

3

4

7

7

7

7

7

7
$21.03 .10-221$

$21.03 .10-222$

$21.03 .10-311$

$21.03 \cdot 10-312$

$21.03 \cdot 10-321$

$21.03 .10-322$

$21.03 .10-999$

21.03 .20

21.03 .30

21. 04

21.05

21.05 .00

$21.05 .00-111$

$21.05 .00-211$

$21.05 .00-212$

$21.05 .00-221$

$21.05 .00-222$

$21.05 .00-311$
NOME DA CONTA

Cana-de-açúcar em produção

Cana-de-açúcar em Eormação

Confinamento de Bovinos

Investimento em Pecuária

de Corte

Camarão em Produção

Investimento em Camarao

Centro de Saídas de Caixa

Indiretas

Encargos Sociais Pagos

outros págamentos

Combustiveis e Lubrificantes

Fertilizantes, Corretivos

Defensivos Sementes e Mudas

Arroz en Crescimento

Seringueira em Produçäo

Seringueira em Formaço

Cana-de-açúcar em Produção

Cana-de-açúcar em Formạ̧o

Confinamento de Bovinos 
Tabela 15. BLENCO DE CONTAS PARA CONTABILIDADE REGIME CAIXA

BMPRBSA RURAL: "Fazenda Próspera"

\begin{tabular}{|c|c|c|}
\hline GRAU & CODIGO & MOME DA CONTA \\
\hline 7 & $21.05 .00-312$ & $\begin{array}{l}\text { Investimento em Pecuária de } \\
\text { Corte }\end{array}$ \\
\hline 7 & $21.05 .00-321$ & Camarão em Produção \\
\hline 7 & $21.05 .00-322$ & Investimento em Camarão \\
\hline 7 & $21.05 .00-999$ & $\begin{array}{l}\text { Centro de Saida de Caixa } \\
\text { Indireta }\end{array}$ \\
\hline 3 & 21.06 & Materiais de Consumo \\
\hline 4 & 21.06 .00 & Materiais de Consumo \\
\hline 7 & $21.06 .00-111$ & $\begin{array}{l}\text { Materiais para Arroz em } \\
\text { Crescimento }\end{array}$ \\
\hline 7 & $21.06 .00-211$ & $\begin{array}{l}\text { Materiais p/ Seringueira em } \\
\text { Formação }\end{array}$ \\
\hline 7 & $21.06 .00-212$ & $\begin{array}{l}\text { Materiais p/ Seringueira em } \\
\text { Produção }\end{array}$ \\
\hline 7 & $21.06 .00-221$ & $\begin{array}{l}\text { Materiais p/ Cana-de-açúcar } \\
\text { em Produção }\end{array}$ \\
\hline 7 & $21.06 .00-222$ & $\begin{array}{l}\text { Mat. p/ Cana-de-açúcar em } \\
\text { Formação }\end{array}$ \\
\hline 7 & $21.06 .00-311$ & Materiais para Confinamento \\
\hline
\end{tabular}


Tabela 15. ELENCO DE CONTAS PARA CONTABILIDADE REGIME CAIXA

BMPRBSA RURAL: "Fazenda Próspera"

\begin{tabular}{|c|c|c|}
\hline GRAU & CODIGO & NOME DA CONTA \\
\hline 7 & $21.06 .00-321$ & $\begin{array}{l}\text { Materiais p/ Camarão em } \\
\text { Produção }\end{array}$ \\
\hline 7 & $21.06 .00-998$ & Materiais p/ a Empresa em Geral \\
\hline 7 & $21.06 .00-999$ & Centro de Saldas Indiretas \\
\hline 3 & 21.07 & $\begin{array}{l}\text { Compra de Animais p/ } \\
\text { criação/Engorda }\end{array}$ \\
\hline 3 & 21.08 & Alimentação Animal \\
\hline 4 & 21.08 .00 & Alimentação Animal \\
\hline 7 & $21.08 .00-311$ & $\begin{array}{l}\text { Ração para Confinamento de } \\
\text { Bovinos }\end{array}$ \\
\hline 7 & $21.08 .00-321$ & Ração para Camarão em produção \\
\hline 3 & 21.09 & Medicamentos e Vacinas \\
\hline 4 & 21.09 .00 & Medicamentos e Vacinas \\
\hline 7 & $21.09 .00-311$ & $\begin{array}{l}\text { Medic } \odot \text { Vacinas } p / \text { Confin. } \\
\text { Bovinos }\end{array}$ \\
\hline 7 & $21.09 .00-321$ & Medic. p/ Camarão em Produção \\
\hline 3 & 21.10 & $\begin{array}{l}\text { Reparos e Manutencao de Maquinas, } \\
\text { Veiculos, Imolementos e } \\
\text { Equipamentos }\end{array}$ \\
\hline
\end{tabular}


Tabela 15. BLENCO DB CONTAS PARA CONTABILIDADE REGIMB CAIXA

BMPRESA RURAL: "Fazenda Próspera"

\begin{tabular}{|c|c|c|}
\hline GRAU & CODIGO & NOME DA CONTA \\
\hline 3 & 21.11 & $\begin{array}{l}\text { Reparos e Manutençao de } \\
\text { Construçoes, Instalaçoes e } \\
\text { Melhoramentos }\end{array}$ \\
\hline 3 & 21.12 & Servicos de Terceiros \\
\hline 3 & 21.13 & Taxas, Impostos, Seguros e Licenças \\
\hline 4 & 21.13 .21 & Taxas e Impostos \\
\hline 4 & 21.13 .22 & Seguros e Licenças \\
\hline 3 & 21.14 & Aluguéis e Arrendamentos \\
\hline 4 & 21.14 .01 & Aluguel do trator de esteira \\
\hline 4 & 21.14 .02 & Aluguel do caminhão \\
\hline 4 & 21.14 .03 & $\begin{array}{l}\text { Aluguel de Depósitos de } \\
\text { Terceiros }\end{array}$ \\
\hline 4 & 21.14 .04 & Arrendamento de Terra \\
\hline . & $\cdot$ & ' \\
\hline 3 & 21.15 & Pagamento do Imposto de Renda \\
\hline 3 & 21.16 & Despesas com Vendas \\
\hline 3 & 21.17 & Despesas Administrativas " \\
\hline 3 & 21.18 & Despesas Financeiras \\
\hline 3 & 21.19 & Outras Saldas \\
\hline 2 & 22. & OUTROS USOS DE CAIXA \\
\hline 3 & 22.01 & PAGAMENTOS DE DIVIDAS \\
\hline
\end{tabular}


Tabela 15. BLENCO DE CONTAS PARA CONTABILIDADR RBGIME CAIXA

EMPRESA RURAL: "Fazenda Próspera"

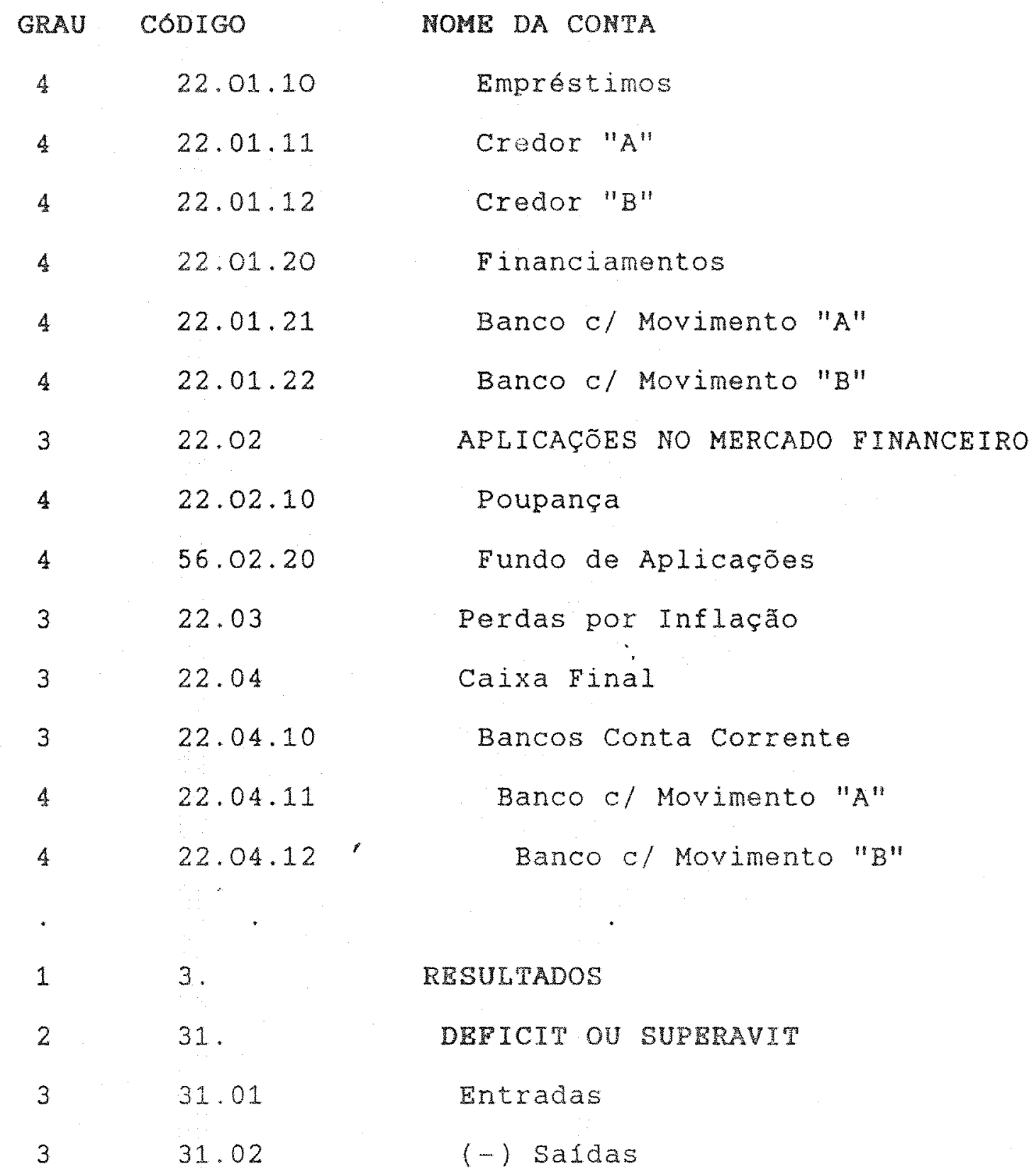


5. CONCLUSAOO

Para que seja possivel apresentar algumas sugestöes, e necessario, primeiramente, avaliar a contribuição deste estudo na área de planejamento e controle.

Com relação ao planejamento, avanços computacionais possibilitaram o desenvolvimento de modelos mais sofisticados, mas o interesse pela funço de controlo em Empresas Agropecuárias foi despertado bem mais recentemente. Verificou-se na literatura que a Iigação existente entre essas duas funções não vinha sendo objeto de estudo. Neste trabalho, o objetivo foi desenvolver um instrumento que possibilitasse o tratamento "em conjunto" dessas funçōes. Esse instrumento deveria pronover, na prática, a ligaçăo' entre o plano gerado por um modelo de planejamento e um sistema de controle contabil. o instrumento que mais se adaptou a esse proposito foi o Demonstrativo de Fluxo de Caixa. Esse Demonstrativo permito monitorar entradas e saldas de caixa a cada bimestre através de um sistema de contas de Fontes e usos de Recursos. Além de essencial ao controle financeiro, o $\mathbb{E}$.C. 6 facilmente extrajdo de modelos de planejamento que 
utilizam P.L. que foi a técnica usada no planejanento.

A comparação do E.C. real com o projetado a a base do sistema de controle, mas esse demonstrativo nao informa sobre o Resultado do periodo contábil. Mudanças não convertidas em caixa não são incluídas no demonstrativo, mas afetam o Resultado do período. Essas mudanças correspondem as variaçōes no estoque de insumos, culturas e animais $\theta$ a depreciação dos bens de capital. Maiores detalhes sobre suas Iimitações são apresentadas por BOEHJE \& ETDMAN (1984).

- modelo de FC proposto para controlo apresenta algumas diferenças em relação a modelos encontrados na literatura. Uma delas 6 distribuicão de entradas e saídas de caixa por atividade agropecuária. Essa estrutura permite a comparação com o FC gerado pelo modelo de P.L.. Além disso, há uma separação entre atividades em produção e investimento. Essa separação favorece uma futura expansão do sistema de controle para que permita o calculo do resultado do periodo. Para que isso fosse possivel, seria necessário utilizar-se um demostrativo de resultado do exercicio.

o plano de contas apresentado possibilita o controle do caixa. O elenco de conta e pequeno e apresenta a vantagem de ser bastante simples. Considerando-se a possibilidade de expansão mencionada acima, sugere-se que sejam inseridas contas para controle de estoque. 


\section{RBFERENCIAS BIBLIOGRAFICAS}

ALBUQUERQUE, M.C.C. de. O perfil do administrador rural: uma proposta curricular. Revista de Administracão de Empresas, Rio de Janeiro, 25(4):41-8, out./dez.1985

ARAÚJO, P.F.C. de \& SHIROTA, R. Crédito e desenvolvimento da agricultura. In: CONGRESSO BRASILEIRO DE ECONOMIA B SOCIOLOGIA RURAL, 25., São Luís, 1987. Anais. Brasilia, SOBER, 1987 p. 99-112

AZEVEDO FILHO, A.J.B.V. de E. PERES, F.C. Competitividade da cultura da soja em uma empresa da região de Campinas, SP. In: EMBRAPA. Planejamento da propriedade agricola - modelos de decisão. Brasilia, 1986. p.289-300.

BARNARD, C.S. \& NIX, J.S. Farm planning and control Cambridge, Cambridge Univ. Press, $1973.549 \mathrm{p}$.

BOEHJE, M.D. \& EIDMAN, V.R. Farm management. Now York, Johr Wiley \& Sons, 1984. 
BOLES, J.N. Linear programming and farm management analysis. Journal of Earm Economics, Local, 37(1):1-24, feb. , 1955

BOUCINHAS, J.F. de C. A aplicação de modelos ao processo de planejamento na empresa. São Paulo, 1972. 153p. (Dou torado - Faculdade de Economia e Administração /USP)

BRULL, T.D. Planejamento do lucro: um modelo integrado de simulação que incorpora o impacto inflacionário. São Paulo, 1983. 174p. (M.S. - Faculdade de Economia e Admi nistração/USP)

CHAVES, R.N. de M. Programação linear num projeto de arma zenamento e secagem de grãos. Viçosa, 1970. 59 p. (M.S. - Universidade Federal de Viçosa)

ESTRAVIZ RODRIGUES, L.C. Planejamento agropecuário através de um modelo de programação linear não determinista. Piracicaba, 1987. 170 p. (M.S. - Escola superior de Agricultura "Luiz de Queiroz"/USP)

FERREIRA, L.R. A introdução de novas atividades produtivas para o desenvolvimento de uma região agricola. A fruticultura na zona da mata de Minas Gerais. Viçosa, 1971. 166 p. (M.S. - Universidade Federal de Viçosa) 
FRANCO JR, C.F. Contabilidade agricola: uma análise histo rica e empirica para o sudoeste brasileiro. Piracicaba, 1984. 128 p. (M.S. - Escola Superior de Agricultura "Luiz de Queiroz"/USP)

HARDAKER, J.B. \& ANDERSON, J.R. Why farm recording systems are doomed to failure, Review of Marketing and Agricultural Economics, Local, 49(3): 199-202, 1981.

HAZELL. P.B.R. A linear alternative to quadratic and semivarianci programming for farm planning under uncertainty. Am. J. Aoric. Econ., Local, 53(1): 53-62, fev. , 1971 .

HOFEMANN, R.; ENGLER, J.J. de C.; SERRANO, O; THAME, A.C. de M.; NEVES, E.M. Administragão da empresa agricola, 5. ed. rev. Säo Paulo, Pioneira, 1987, 325 p.

JONES, B.L.; SONKA, S.T.; MAZZOCCO, M.A. Agricultural record systems and the information needs of farmers and lenders.. Agricultural Finance Review, Local, 42:40-45, 1982.

KOONTZ, H.; DONNELL, C.; WEIHRCH, H. Administracäo-organização, planejamento e controle. 14, ed. São Paulo, Pioneira, 1986-87. $536 \mathrm{p}$. 
MAXIMIANo, A.C.A. Introducão à administração, 2. ed. São Paulo, Atlas, 1988.315p.

MESQUITA, A. Análise econômica da habilidade da produção de café na competição de recursos em "empresas tipicas" da zona da mata de Minas Gerais. Viçosa, 1971. 203 p. (M.S. - Universidade Federal de Viçosa)

NORONHA, J.F. Projetos agropecuários: administração finan ceira, orçamentação e avaliação econômica. Piracicaba, FEALQ, 1981.274 p.

OLIVEIRA, A.J. de. Análise econômica da exploração floreṣ tal e sua combinação com outras atividades, pela progra mação linear, zona da Mata, Minas Gerais. Viçosa, 1971. 171 p. (M.S. - Universidade Federal de Viçosa)

OLIVEIRA FILHO, J. de. Sistema de informações gerenciais para empresas cacaueiras: o caso da CEPLAC. Piracicaba, 1989. 203 p.(M.S.- Escola Superior de Agricultura "Luiz de Queiroz"/USP)

PATERSON, G. Computers in agriculture. Farmers Club Journal, Local, 59: 8-20, 1982. 
PERES, F.C. Estratégias de redução de risco no planejanen to das empresas. - Notas do curso de planejamento

e administracão de empresa agropecuária. Piracicaba, EEALQ /ESALQ , 1988, p.1-24

PINTO, S.L. de M. Microcomputadores: um estudo sobre a im plantação na pequena e média empresa com base numa meto dologia de enfoque sistêmico. São Paulo, 1987. 159p. (M.S. - Eaculdade de Economia e Administração /USP)

REZENDE, G.L. de. Politica Agrícola, preço da terra $\theta$ es trutura agrária. In: CONGRESSO BRASILEIRO DE ECONOMIA E SOCIOLOGIA RURAL, 20., Brasilia, 1982. Anais. Brasilia, SOBER, $1982 \cdot \mathrm{p} .73-89$

RODRIGUES, S.R. Cooperativismo e crédito rural. In: CONGRESSO BRASILEIRO DE ECONOMIA Ė SOCIOLOGIA RURAL, 25. São Luís, 1987. Anais. Brasilia, SOBER, 1987.p. 113-

SANTOS, M.L. de M. 'A questão de oferta ruxal em um contex to de politica monetária restritiva - um ensaio sobre o caso brasileiro. In: CONGRESSO BRASILEIRO DE ECONOMIA E SOCIOLOGIA RURAL, 22, 1984. Anais. Brasilia, SOBER, $1984, p .245-269$ 
SANTOS, N.R.S.M. Contabilidade rural: Um enfogue gerencial. Piracicaba 1991. 275p. (M.S. - Escola superior de Agricultura "Luiz de Queiroz"/USP).

SUGAI, Y. Planejamento básico de uma empresa agropecuária pela programação linear. Viçosa, 1967. p. (M.S. - Universidade Federal de Viçosa)

TEIXEIRA FILHO, A.R. Análise e avaliação das pesquisas em administração rural e economia da produção no Brasil. In: CONGRESSO BRASILEIRO DE ECONOMIA E SOCIOLOGIA RURAL, 10., Brasilia, 1974. Anais. Brastlia, SOBER, 1974. v. 5, p. $13-36$

TUNG, N.H. Controladoria financeira das empresas: uma abordagem prática. 7. ed. São Paulo, Edições Universidade - Empresa Ltaa, 1985. $447 \dot{\text { p. }}$

TUNG, N.H. Orsamento empresarial no Brasil - para empresas industriais'e comerciais. 3. ed. São Paulo, Ediçōes Universidade - Empresa, Ltda, 1983. 392p.

TUNG, N.H. Planejamento e controle financeiro das Empresas Agropecuárias. São Paulo, Ediçöes Universidade Empresa, 1990. 382 p. 
VEIGA, A. Agricultura, estado e privatização. In: CONGRES SO BRASILEIRO DE ECONOMIA E SOCIOLOGIA RURAL, 25., São Luis, 1987. Anais. Bras11ia, SOBER, 1987. p. 99-112

WILSON, B. \& MACPHERSON, G. Computers in farm management. London, Northwood Book, 1982. $176 \mathrm{p}$. 


\begin{abstract}
ANEXO
LEVANTAMENTO DAS CLASSES DE CAPACIDADE DB USO DOS SOLOS DA FAZENDA "PROSPERA"
\end{abstract}

\author{
RELATÓRIO ${ }^{2}$

\section{planejamento agrícola}

- trabalho de planejamento agricola, consta de um agrupamento bastante abrangente e geral sobre os dados da propriedade; ele vai levar em consideraça para ocupação da área, desde tendências de mercado até gosto e tradição do proprietário.

Este trabalho, vai apresentar um mapa com as classes e subclasses de Capacidade de Uso. Esta classificação vai indicar qual o melhor uso para a área, estando implicito nela os conceitos de conservaça de solos. Para a confeç̧ão do mapa de Capacidade de Uso, foram necessários vários passos a saber:

- estudo do mapa planialtimétrico da

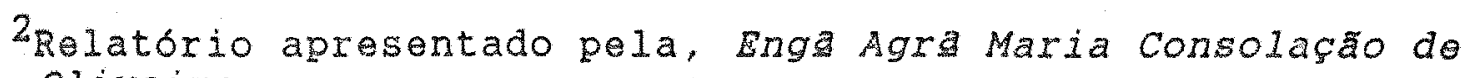
oliveira 
Fazenda Jequitibá em escala de 1:2000, apresentado pelo proprietário

- estudo da Carta de Restituiça em escala de 1:10000, adquirida no Instituto Geogrático e Cartográfico em São Paulo

- preparo, apos estudo de relevo e principais pontos de drenagem e acúmulo de água, do mapa de classes de declives

estudo do Boletim do Levantamento Pedológico semidetalhado dos Solos do Estado de São Paulo e Quadricula de Campinas do IBGE, escala de 1:50000

- levantamento das principais unidades taxonomicas que abrangem a área

- atualização do mapa de uso atual $\theta$ coleta de dados sobre o manejo das culturas

- estudo sobre locação de talhöes na planta de talhöes já existentes

Acompanha também o mapa, a descrição que se segue com as principais caracteristicas dos solos encontrados na Fazénda, o manejo mais adequado conforme a classificação quanto à melhor utilização.

Principais Unidades Taxonônicas dos Solos Encontradas no Levantamento pedologico semidetalhado dos Solos do Estado de São Paulo - Quadricula de Campinas - IBGE

\author{
Unidade Valinhos PV-6
}

Classificação: Podzólico Vermelho Amarelo 
Apresenta horizonte superficial A moderado, textura argilosa, relevo suave ondulado a ondulado.

Esta unidade compreende solos que apresentam amplas variações de caracteristicas principalmente morfológicas. São solos profundos, com sequência de horizontes $A, B, C$, os quais se apresentam bem diferenciados no campo.

A caracteristica predominante é a presença de um horizonte "B" argilico de coloração vermelha $\theta$ amarelo avermelhado desenvolvido em material proveniente do intemperismo de rochas com complexo cristalino, principalmente granitos e gnaisse.

São solos ácidos a muito ácidos, com baixa soma de bases e valor médio de saturação em bases, contudo há grande dispersão dos valores encontrados e apesar da ocorrência do aluminio trocável ao' longo do perfil, não apresentam caráter álico.

A vegetação original é representada pela mata latifoliada trópical, a ocupação atual desses solos é com pasto, café e cana-de-açúcar.

Unidade Usina Py-2

Classificação: Podzólico vermelho

Amarelo-álico

Apresenta horizonte de superficie A, moderado, relevo suave ondulado. 
Os solos dessa unidade apresentam um horizonte "A" moderado, arenoso, assente sobre um horizonte "B" textural, profundo, com textura média. São solos muito ácidos com baixos valores de soma de saturação em bases e em aluminio trocável ao longo do perfil, capaz de determinar caráter álico.

- relevo suave ondulado se desenvolve preferencialmente entre as cotas de 620-670 $\mathrm{m}$, enquanto que no relevo ondulado as cotas variam de 500-620 m. A declividade no primeiro caso varia de 4 a 78 enquanto que no segundo chega a atingir 158 .

o material de origem é proveniente do retrabalhamento de arenitos finos do grupo Tubarão.

A vegetação original era, predominantemente, a mata latifoliada tropical, a utilização mais frequentes desses solos é com cultura de citrus e cana, culturas anuais, pastagem e reflorestamento.

\section{Unidade Camarguinho LH}

Classificação: Latossolo Vermelho Amarelo Húmico álico textura barrenta ou argilosa, relevo aplainado ou suavemente ondulado.

Apresenta-se com horizonte superficial A proeminente, com espessura a $100 \mathrm{~cm}$ assente sobre um $B$ latossólico muito friável, bastante poroso e profundo.

são solos muito ácidos, com soma $\theta$ saturação em bases muito baixas e aluminio relativamente 
elevado ao longo do perfil.

Esta unidade ocorre em superficies de relevo aplainado a suave ondulado, em geral, no limite dessas com superficies mais dissecadas. A altitude varia de 589 a 650 metros.

- material de origem resulta do retrabalhamento de sedimentos barrentos e argilosos do grupo Tubarão.

A vegetação original era principalmente o cerrado, contudo encontrou-se mata de pasto muito bom nesta unidade.

\section{Unidade Mato Dentro LV-1}

Classificação: Latossolo Verme tho Amarelo,

álico

"A" moderado, textura argilosa, relevo aplainado ou suave ondulado.

A unidade Mata Dentro é Constituía por solos profundos e bem drenados, porosos, com textura barrenta ou arigilosa no horizonte "A" e argilosa no horizonte "B". O horizonte "A", moderado, está assente sobre un "B" latossólico, espesso, bastante homogêneo e de textura argilosa.

São solos muito ácidos, apresentando em condiçōes naturais valores muito baixos de soma e saturação em bases além de alumínio trocável.

o relevo e aplainado a suave ondulado com 
doclives on geral inferiores a 58 e a ativude varia do 580 s.

o material do origen resulta do retrabalhamento de materiais proenintes de sedimento

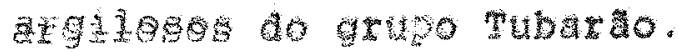

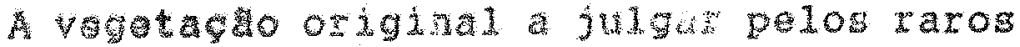
tomanogenta anconts latifoliada tropical o corada.

Os solos dessa unidade são exploxados intensamente com plantio de cana-de-açucar, citrus o culturas anuais.

\section{CLASSES DE CAPACTDADE DE USO}

Dadas as caractorigticas o propriedades

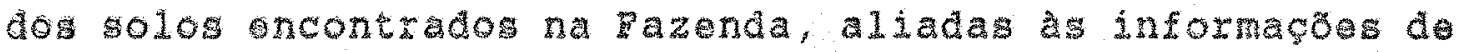

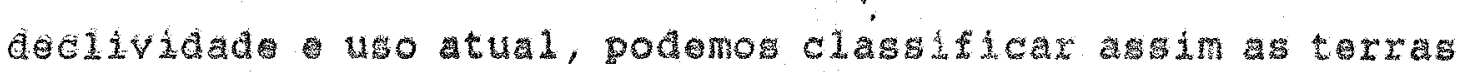

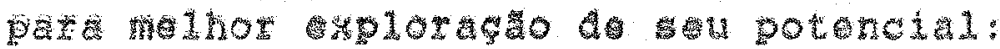

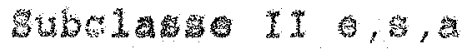

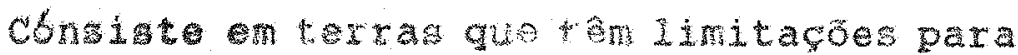

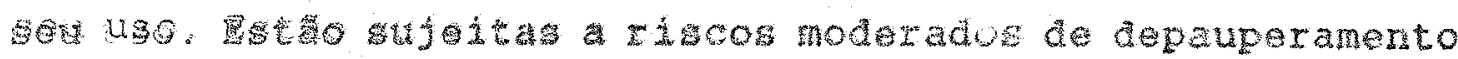

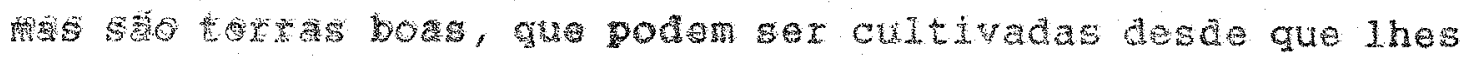

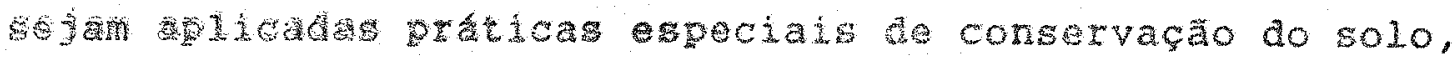
de fact exocuga, para produça sagura e permanonte de colholtas arte weiss e elevadas, de cunturas anuas actoradas regido.

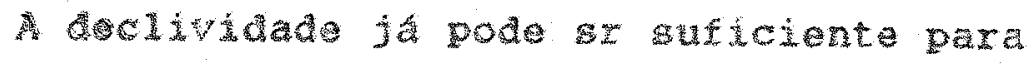


provocar enxurradas e erosão (classe "B" de declive). Rm terras planas, podem requerer drenagem, sen práticas complexas de manutençäo dos drenos, caso da subclasse IIa. Cada una dessas limitaçöes requer culdados especiais, como arąăo e plantio en contorno, plantas de cobertura, cultura en faixas, controle de agua, proteção contra enxurradas advindas de glebas vizinhas, além de rotação de cultura e aplicacoos de corretivos e fertilizantes, já que para a subclasse IIs conta-se com a baixa capacidade de troca, baixa saturacão de bases.

Paralelo com a condição atual e sugestões:

Atualmente ha plantio de milho rotacionado com fejJão, na área, o que está correto ao se observar a prática de rotaço de culturas que é recomendada tecnicamente pela classificaçäo. No entanto, a aplicaça de corretivos e fertilizantes deve ser revista, para tal, uma nova amostragem de solo deve ser feita no local.

A adubaço que é destinada à cultura de milho de $700-800 \mathrm{~kg} / \mathrm{alq}$ de NPK em 4-14-8 näo chega a atender as exigencias da cullura, já que o solo apresenta baixa capacidade de retença de adubo.

Quanto à drenagem, os drenos deven perfazer o caminho que mais facilite a saida da agua já que o solo, assim o permite, portanto novos arenos devem ser alocados para melhor facilitar a sua manutencão.

Subclasse III e, s

As terras classificadas nesta subclasse, 
estão sujeitas a severos riscos de depaupertamento, principalmente no caso de culturas anuais. Requerem medidas intensas e complexas de conservação do solo, a fim de garantirem permanentemente, produção de média a elevada das culturas.

As terras que apresentam declividade moderadas (classe de declive "C"), de relevo suavemente ondulado a ondulado, com deflúvio rápido para o solo LV-1 podem causar problema quanto a riscos severos de erosa laminar e sulcos superficias e rasos frequentes em terrenos que mesmo com declive de classe B, sendo do solo pV-2 ou pV-6. Dal a subclasse de capacidade de uso IIIs.

Ainda na subclasse III $s$, as terras de declive $B$ com fertilidade muito baixa (caráter álico) solo PV-2 e que apresentam dificuldades no preparo do solo devido a presença de pedras e argilas expansiva, perfazem o total da área aqui retratada.

paralelo com a condição atual e sugestōes:

Estas terras incluem o pomar da sede, a criaça de porcos e'o café que existe ali pelas redondezas como mostra o mapa. Por serem culturas perenes e o café apresentar pouco tempo de idade, abm de boas condiçoss, podemos preservâ-10 e dessa area, separadanente, também retirarmos amostra para análise quimica, a fim de fazer adubaçăo diferenciada aos distintos kipos de solo e idade dos cafezais.

Não convern a colocação de culturas anuais 
nestas áreas, para não revolver mais o terreno, justamente nesta posição do relevo em solo mais susceptivel à erosão. Subclasse IVe, a

Aqui convém separar-se os fatores limitantes das áreas que envolvem as subclasses IVa e IVa. IVa: Pelo seu fator limitante ser a diflcil drenagem, dificultando a motomecanização e pelo fato do risco de inundação ocasional existir, o que impede o cultivo continuo, fica limitada a escolha da especie a se cultivar, restringindo àquelas que são tolerantes a condiça de encharcamento.

IVe,s: O fator limitante desta subclasse de capacidade de uso, reside no risco de erosão para cultivos intensivos, por apresentarem declividade acentuada (classe "D" de declive), com deflúvio muito rápido (solo LV-1), podendo apresentar erosão em sulcos superficiais muito frequentes, em sulcos rasos frequentes ou sulcos profundos ocasionais; também é o caso de terrenos com declives da classe $C$, para solos $P V-2$ e PV-6, susceptiveis a erosão.

Também nesta subclasse IVs, os solos são limitados pela aparente pedregosidade $(30-508)$ e problema de fertilidade (caráter álico).

Paralelo com a situaça atual e sugestós:

A área de classe de declive "A", inundada, em que se cultiva arroz, está com a ocupaça correta, no entanto, para se obter melhores produçóes de arroz, convém 
retirar-se daqui também as análises de solo com a finalidado de melhor especificar o aduto, visto que, nos últimos tempos a produção de arroz tem minguado.

Quanto à classe de declive $C$ e $\mathrm{D}$ que se apresenta com o plantio de café, aquelas que não tiverem os pés de café abandonado, podem permanecer com a promessa de que futuramente se dispensará maior atença a elas devi do ao abandono e reestruturaça de antigas areas de cafo.

No declive de classe "C" para solos PV-2 e PV-6, é recomendável, mesmo que em cultura perene, a formação de terraços de contençào de água para seus escoadouros naturais, observados no terreno.

o sistema de irrigação que satisfaz a cultura em suas necessidades hidricas, deve ser revisto, para assegurar nestas classes de declives mais problemáticas, onde se manterá talvez o café, a conservação dos solos em questão.

As pequenas ou consideráveis áreas que continuarem com culturas anuais, devem ser replanejadas com a cultura perene que se escolher para a subclasse de capacidade de uso a seguir ou mesmo com as áreas com café abandonado, que entram neste planejamento.

Quanto à esta classe de capacidade de uso que apresentar pasto como ocupaça, podu manter-se assim caso haja interesse no momento da escolha das ocupaços das classes que ainda restam.

Subclasse VIe, s 
Terras improprias para culturas anuais, mas que podem ser usadas para produço de certos cultivos permanentes úteis como pastagens, florestas e algumas culturas permanentes protetoras do solo, como: seringueira e cacau, desde que adequadamente manejadas.

o uso com pastagens ou culturas permanentes protetoras deve ser feito com restriçōes moderadas, com práticas especiais de conservação do solo, uma vez que ainda assim, existe o risco de depauperamento do solo, pela própria movimentação de, um dia, já ter sido retirada sua vegetação original.

Normalmente, as Iimitaços que apresentam são em razão da declividade excessiva - classes do declividade "E" para os solos LV-1 e declive "D" para os solos PV-2 e PV-6_ dificuldades severas de motomecanizaça pelas condiçōes topográficas, com risco de erosão que pode chegar a muito severo, presença de erosão em sulcos rasos muito frequentes ou sulcos profundos frequentes.

Mecanização ainda impedida pela presença de pedregosidade $\left(30^{\prime}-50 \%\right)$ e/ou rochas expostas à superficie.

Paralelo com a situação atual e sugestões:

Visto que a cultura escolnida para ocupar estas terras até hoje foi o café e isto ultimamente não vem sendo viável, devido ao estado de abandono a que se encontram tais areas, pois hoje temos majo-de-obra retrita $\theta$ a motomecanizaçäo näo atinge esta área, pela sua natural condição de intensa declividade; sugere-se o abandono total 
- partida para uma cultura adequada, de recobrimento total da area, que the assegure dos riscos maiores de erosaro.

A pastagem para isto se presta bem, no entanto, existe ainda o inconveniente quanto ao declive, que vai restringir o sistema de criação animal que ira pastar este capim, e até mesmo o porte do animal.

Porém, como já foi citado, existem outras culturas de recobrimento para a área como a seringueira, além da hipótese do reflorestamento ou criação de animais silvestres, que é justamente a proposta mais correta para a classe seguinte.

\section{Subclasse VIIe, S}

Esta classe apresenta severas limitaçoses mesmo para culturas permanentes protetorss do solo, pastatens e florestas.

Por apresentarem estas terras, declividades bastante acentuadas (classe de declive "p"3 a deficiência de água também é muito grande já que a esta altura, o solo apresenta uma taxa de pedregosidade mais elevada baixa capácidade de retença de água.

Paralelo com a situção atual e sugestőes:

Seu uso para pastagens como para reflorestamento para produço de madeira requer cuidados

${ }^{3}$ A classe "g" de declive implica na existencia de declividade maiores que 25 porque a escala utilizada para o armazenamento 6 de 1:2000, o que permite chegarmos ate esta classe que 6 suficientemente abrangente de problemas e soluços de converço de solo, ate mesno citadas em classes anteriores. 
muito especiais, porém 6 a alternativa mais correta. Portanto, não existe razão para so pensar, ainda assim, em caf́́ como ocupação Iinal desta area, embora ela representasse a maior parte da propriedade.

Convém lembrar que a persistencia da manutenção do café nas áreas já existentes en que ele será aproveitável, defende apenas o interesse de usufruir por mais tempo de toda a infra-estrutura montada no passado para atender a esta necessidade, desde mäo-de-obra até equipamentos.

\section{Carreadores}

os carreadores não serao locados em planta, porque a formacão elou reforma dos que já existem será função da ocupação nova das glebas.

Não podemos nos esquecer, que uma infinidade de carreadores que possam facilitar o caminho para transporte de material ou coleta de produto, também consome boa parte da área, além de exigir uma manutenço constante, visto sua susceptibilidade è erosa.

Enfim, quantos forem os carreadores, eles devem obedecer às leis conservacionistas do terreno, na permitindo que, por apenas comodidade, seu tracado não seja - correto. O correto traçado para um carreador, 6 a menor distância que vai ligar os pontos desejados tomando-se o cuidado sempre, para que ele quebre velocidade e corte o caminho natural que à agua pexcorre. 